Portland State University

PDXScholar

$6-21-2011$

\title{
In Situ Enrichment of Ocean Crust Microbes on Igneous Minerals and Glasses Using an Osmotic Flow-Through Device
}

\author{
Amy Renee Smith \\ Portland State University \\ Martin Fisk \\ Oregon State University \\ Radu Popa \\ Portland State University \\ Mark Nielsen \\ Harvard University \\ C. Geoffrey Wheat \\ University of Alaska Fairbanks
}

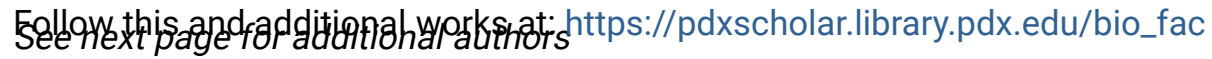

Part of the Environmental Microbiology and Microbial Ecology Commons Let us know how access to this document benefits you.

\section{Citation Details}

Smith, A., R. Popa, M. Fisk, M. Nielsen, C. G. Wheat, H. W. Jannasch, A. T. Fisher, K. Becker, S. M. Sievert, and G. Flores (2011), In situ enrichment of ocean crust microbes on igneous minerals and glasses using an osmotic flow-through device, Geochemistry Geophysics Geosystems, 12(6), Q06007.

This Article is brought to you for free and open access. It has been accepted for inclusion in Biology Faculty Publications and Presentations by an authorized administrator of PDXScholar. Please contact us if we can make this document more accessible: pdxscholar@pdx.edu. 


\section{Authors}

Amy Renee Smith, Martin Fisk, Radu Popa, Mark Nielsen, C. Geoffrey Wheat, Hans W. Jannasch, Andrew T. Fisher, Keir Becker, Stefan M. Sievert, and Gilberto Flores 

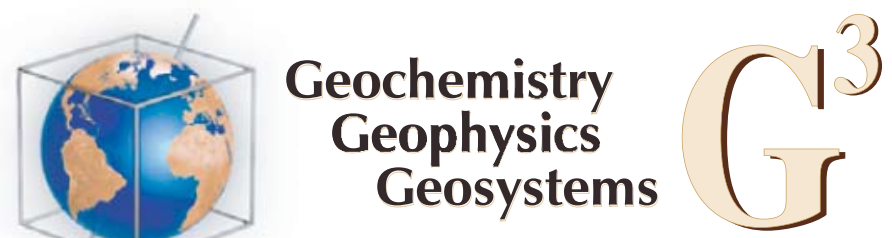

\title{
In situ enrichment of ocean crust microbes on igneous minerals and glasses using an osmotic flow-through device
}

\author{
Amy Smith and Radu Popa
}

Department of Biology, Portland State University, Portland, Oregon 97201, USA (smitar@pdx.edu)

Martin Fisk

College of Ocean and Atmospheric Sciences, Oregon State University, Corvallis, Oregon 97331, USA

Mark Nielsen

Organismic and Evolutionary Biology, Harvard University, Cambridge, Massachusetts 02138, USA

\section{Geoffrey Wheat}

School of Fisheries and Ocean Sciences, University of Alaska Fairbanks, Fairbanks, Alaska 99775, USA

Hans W. Jannasch

Monterey Bay Aquarium Research Institute, 7700 Sandholdt Road, Moss Landing, California 95039, USA

Andrew T. Fisher

Earth and Planetary Sciences, University of California, Santa Cruz, California 95064, USA

Keir Becker

Rosenstiel School of Marine and Atmospheric Science, University of Miami, Miami, Florida 33149, USA

Stefan M. Sievert
$\quad$ Woods Hole Oceanographic Institution, 266 Woods Hole Road, Woods Hole, Massachusetts O2543, USA

Gilberto Flores

Department of Biology, Portland State University, Portland, Oregon 97201, USA

[1] The Integrated Ocean Drilling Program (IODP) Hole 1301A on the eastern flank of Juan de Fuca Ridge was used in the first long-term deployment of microbial enrichment flow cells using osmotically driven pumps in a subseafloor borehole. Three novel osmotically driven colonization systems with unidirectional flow were deployed in the borehole and incubated for 4 years to determine the microbial colonization preferences for 12 minerals and glasses present in igneous rocks. Following recovery of the colonization systems, we measured cell density on the minerals and glasses by fluorescent staining and direct counting and found some significant differences between mineral samples. We also determined the abundance of mesophilic and thermophilic culturable organotrophs grown on marine R2A medium and identified isolates by partial $16 \mathrm{~S}$ or $18 \mathrm{~S}$ rDNA sequencing. We found that nine distinct phylotypes of culturable mesophilic oligotrophs were present on the minerals and glasses and that eight of the nine can reduce nitrate and oxidize iron. Fe(II)-rich olivine minerals had the highest density of total countable cells and culturable organotrophic mesophiles, as well as the only culturable organotrophic thermophiles. These results suggest that olivine (a common igneous mineral) in seawater-recharged ocean crust is capable of supporting microbial communities, that iron oxidation and nitrate reduction may be important physiological characteristics of ocean crust microbes, and that heterogeneously distributed minerals in marine igneous rocks likely influence the distribution of microbial communities in the ocean crust. 
Components: 11,800 words, 7 figures, 5 tables.

Keywords: Juan de Fuca; basalt; iron oxidizers; nitrate reducers; olivine; subseafloor.

Index Terms: 0448 Biogeosciences: Geomicrobiology; 0450 Biogeosciences: Hydrothermal systems (1034, 3017, 3616, 4832, 8135, 8424); 0463 Biogeosciences: Microbe/mineral interactions.

Received 29 October 2010; Revised 20 April 2011; Accepted 26 April 2011; Published 21 June 2011.

Smith, A., R. Popa, M. Fisk, M. Nielsen, C. G. Wheat, H. W. Jannasch, A. T. Fisher, K. Becker, S. M. Sievert, and G. Flores (2011), In situ enrichment of ocean crust microbes on igneous minerals and glasses using an osmotic flow-through device, Geochem. Geophys. Geosyst., 12, Q06007, doi:10.1029/2010GC003424.

\section{Introduction}

[2] Much of the earth's microbial biomass exists in the subsurface, and a sizable fraction of this is in ocean sediments and igneous rocks [Whitman et al., 1998]. If microbial life in the igneous ocean crust extends to the depth of the $\sim 120^{\circ} \mathrm{C}$ isotherm (commonly thought to be the upper temperature limit of life) then the volume of rock available for microbial colonization is about the same as the volume of the oceans [Heberling et al., 2010]. Most of this volume is difficult to sample but microorganisms have been identified from igneous layers of the ocean crust [e.g., Mason et al., 2010]. Additional understanding of the deep igneous biome comes from microorganisms extracted from subsurface fluids [e.g., Cowen et al., 2003], although unattached microorganisms in aquifer fluids are not necessarily representative of the microorganisms attached to the host rocks [Lehman, 2007]. Microbes may also preferentially attach to specific minerals in the host rocks, but because oceanic igneous rocks are typically mineralogically heterogeneous on the 0.01 to $10 \mathrm{~mm}$ scale and cell abundances are low, current analytical techniques are inadequate for determining what microorganisms are associated with specific minerals.

[3] A new approach for determining microbial preference for igneous minerals uses in situ colonization of target mineral substrates housed in flow-through cells [Fisher et al., 2005a; Smith et al., 2008; Orcutt et al., 2010a, 2010b]. This approach combines monomineral substrates in isolated chambers with osmotically driven pumps that draw formation water through the chambers. Once the chambers are recovered, each mineral type can be processed to determine the degree of microbial colonization, the phylogeny of community members, community complexity and microbial diversity, physiology using culture based studies, and mineral weathering. Here we report initial findings from a 4 year flow cell incubation in the deep ocean subsurface of the eastern flank of the Juan de Fuca Ridge (JFR). This is one of two experiments of this type [Orcutt et al., 2010a, 2010b; Smith et al., 2008], although it is the first to incubate a wide diversity of igneous minerals using fluid drawn across the samples with an osmotic pump.

[4] Subsurface microorganisms are diverse and include all domains of life (Bacteria, Archaea, and Eukarya) and appear to colonize ocean crust basalt via subseafloor fluid transport [Huber et al., 2006; Santelli et al., 2008; Mason et al., 2010]. Microbes living in seafloor and subseafloor volcanic environments include psychrophiles, mesophiles, and thermophiles; aerobes and anaerobes; organotrophs and chemolithotrophs; and respiratory and fermentative autotrophs and heterotrophs. Microbial physiologies that are believed to be linked to geochemical cycles in subseafloor habitats include $\mathrm{Mn}$ (II) and $\mathrm{Fe}$ (II) oxidation [Templeton et al., 2005a, 2005b; Edwards et al., 2003a, 2003b], Fe(III) reduction [Kashefi et al., 2002; Kashefi and Lovley, 2003; Ver Eecke et al., 2009], methanotrophy [Beal et al., 2009], $\mathrm{NH}_{4}^{+}$ oxidation [Hatzenpichler et al., 2008], $\mathrm{NO}_{3}^{-}$reduction [Cowen et al., 2003; Wheat et al., 2010], heterotrophy [Cowen et al., 2003], hydrocarbon degradation [Mason et al., 2010; Kniemeyer et al., 2007], sulfur oxidation [Rathsack et al., 2009], and sulfur and sulfate reduction [Zhou et al., 2009; Nakagawa et al., 2006; Kniemeyer et al., 2007]. Yet with few exceptions [Orcutt et al., 2010a, 2010b], earlier analyses focused on microbes from whole basalt and had a limited capacity to describe the spatial distribution of microbial populations. In addition, culturing and DNA-based studies may be inadequate to fully evaluate the role of subseafloor microbes in geochemical cycling and mineral weathering. To better understand the subseafloor distribution of microbial communities, new methods are required that combine monomineralic substrate incubations in subsurface water with cell density measurements, 
culturing, and DNA analyses. These methods will also help assess the impact of subseafloor communities on geochemical cycling of elements and the weathering of basalt [Stevens, 1997; Thorseth et al., 2001; Daughney et al., 2004; Amend and Teske, 2005; Santelli et al., 2008].

[5] The microbiology of JFR is known from studies of surface and subsurface basalts, hydrothermal deposits, and thermal fluids. Fluids emanating from the $64^{\circ} \mathrm{C}$ IODP Hole 1026B contained nitrate reducers, sulfate reducers, and fermentative heterotrophs originating from the subsurface [Cowen et al., 2003]. Black rust formed by venting fluids at Hole 1026B contained similar organisms found in the subsurface fluid, and the community was dominated by fermenters, sulfate reducers, and methanogens [Nakagawa et al., 2006]. Also, electron microscopic examination of rocks collected from Hole 1026B revealed microorganisms associated with secondary minerals [Fisk et al., 2000]. Samples collected from nearby $20^{\circ} \mathrm{C}$ Baby Bare springs were diverse but interestingly did not include a dominant organism from Site 1026B [Huber et al., 2006]. Mineral and basalt chips incubated in passive flow in Hole 1301A revealed DNA sequences largely from Firmicutes, yet SEM images indicate low-temperature iron oxidizers may have been present when seawater influx and cooler temperatures prevailed [Orcutt et al., $2010 \mathrm{~b}]$. Analysis of natural samples of basalt, metalliferous sediment, and sulfides that were exposed to $\sim 3^{\circ} \mathrm{C}$ bottom water revealed the presence of chemoautotrophic iron-oxidizing bacteria [Edwards et al., 2003a, 2003b], as well as functional genes for carbon fixation, nitrogen fixation, methane oxidation, and methanogenesis [Mason et al., 2009]. Additional microbial diversity has been revealed from hydrothermal chimneys (Schrenk et al. [2003], Ver Eecke et al. [2009], and others). Of these studies, those by Cowen et al. [2003], Nakagawa et al. [2006], Orcutt et al. [2010b], and Huber et al. [2006] provide insight into the microbiology of the subsurface igneous ocean crust. We hypothesized in crafting the present study that minerals with more available redox energy at the mineral-liquid interface will have a greater abundance of microbial cells attached to the mineral surface than the minerals with less available energy.

\section{Materials and Methods}

\subsection{Study Site Description}

[6] Juan de Fuca Ridge (JFR) is a zone of volcanic and hydrothermal activity on the Eastern Pacific rim [Fisher et al., 2005a]. On the eastern flank of JFR, the ocean floor consists of sediments overlaying igneous ocean crust [Underwood et al., 2005]. During IODP Expedition 301 in 2004, several ridge flank boreholes were instrumented including Hole 1301A [Fisher et al., 2005a] (Figure 1a). Hole $1301 \mathrm{~A}$ is situated at $47^{\circ} 45.210^{\prime} \mathrm{N}, 127^{\circ} 45.833^{\prime} \mathrm{W}$ where the water depth $2667 \mathrm{~m}$ and the upper volcanic crust is $3.5 \mathrm{Myr}$ old. The hole has total depth of $369.7 \mathrm{~m}$ below the seafloor (mbsf) with the upper $262.2 \mathrm{~m}$ composed of marine sediment and the lower $107.5 \mathrm{~m}$ composed of basalt (Figure 1b). This basalt is typical of ocean crust Layer 2A (highly porous and permeable pillow lavas and sheet flows containing plagioclase feldspar, pyroxene, and olivine) [Fisher et al., 2005a; Becker and Fisher, 2008]. Upper basement rocks around Hole 1301A are characterized by elevated temperatures $\left(\sim 60^{\circ} \mathrm{C}\right.$ at the sediment-basalt interface) low oxygen, neutral to slightly alkaline $p H$, and an influx of nitratebearing $(>10 \mu \mathrm{M})$ seawater [Wheat et al., 2010]. Although we did not test for total dissolved organic carbon (DOC) in 1301A fluids, nearby Baby Bare Spring and IODP Hole 1026B are reported to have low total DOC $(10-15 \mu \mathrm{M})$ compared to bottom seawater $(38 \mu \mathrm{M})$ [Walker et al., 2008; McCarthy et al., 2011; Lang et al., 2006]. Hole 1301A was fitted with a Circulation Obviation Retrofit Kit (CORK) [Fisher et al., 2005b], which was designed to seal the borehole from the ocean and to suspend instruments in the hole (Figure 1c). This provided a unique opportunity to study the differential microbial colonization of igneous phases in situ.

\subsection{Microbial Flow Cell Design and Implementation}

[7] Igneous specimens were acquired from various sources (Ward's Geology, Unimin Co., seafloor basalt glass). Because the osmotic system pumps low volumes of fluid (on the order of $30 \mathrm{~mL}$ per year), we minimized the amount of free volume and increased mineral surface area by using minerals and glasses that were crushed and sieved to obtain uniform grain sizes between $0.6 \mathrm{~mm}$ and $2.0 \mathrm{~mm}$. Each flow cell held four mineral or glass specimens that were exposed to borehole water in sequence (Figure 2, Table 1) [Fisher et al., 2005a; Smith et al., 2008]. The flow-through colonization systems described by Orcutt et al. [2010a] are similar in design and function to those used in this study [Smith et al., 2008]. The flow cells are $67 \mathrm{~mm}$ in diameter and $70 \mathrm{~mm}$ tall PVC cylinders, each with four incubation chambers $(13 \mathrm{~mm}$ in diameter and $42 \mathrm{~mm}$ deep cylindrical spaces milled into the PVC) 

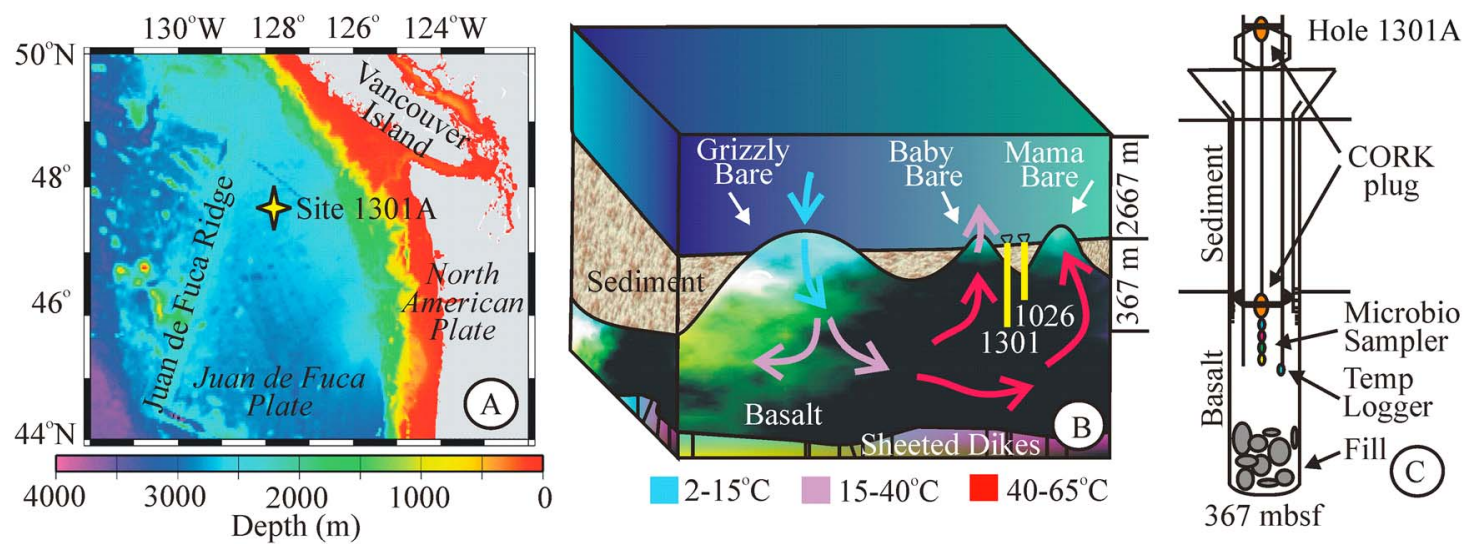

Figure 1. (a) Location of IODP Site 1301A on the eastern flank of Juan de Fuca Ridge (modified from Fisher et al. [2005b]). (b) Stylized cartoon of fluid flow in the basalt basement near Hole 1301A indicated by blue (cool seawater) to red (hydrothermal water). Cold bottom seawater is predicted to enter the ocean crust at the Grizzly Bare outcrop, $52 \mathrm{~km}$ to the south, and warms by lithospheric heating as it flows north-northeast toward Baby Bare and Mama Bare, where at least some of the water exits as springs from these outcrops [Wheat and Mottl, 2000; Wheat et al., 2002; Fisher et al., 2003]. This cycle is predicted to take up to hundreds of years to complete [Elderfield et al., 1999; Walker et al., 2008; Fisher et al., 2003; Hutnak et al., 2006]. (c) Simplified diagram of Hole 1301A (modified from Fisher et al. [2005b]) depicting the CORK and instrument string layout. Microbial flow cells were incubated in the basalt basement (Microbio Sampler) near a temperature logger.

lined with Teflon (Figure 2). We chose a closed system to avoid contamination of the minerals during deployment and recovery and to allow us to compare experimental samples to sterile controls. This closed system required a controlled water flow that was achievable through the addition of an osmotic pump to each flow cell pair. The osmotic pump design has the advantage of providing a low-rate continuous flow for several years [Jannasch et al., 2004]. "In series" and "in parallel" flow designs were considered, and we chose "in series" to eliminate the stagnation of fluid flow through the chambers with the lowest permeability (i.e., fluid channeling), which would happen if the chambers were arranged in parallel. Unequal permeability could occur by packing of minerals with different shapes or grain sizes and clogging of pore spaces with biological material or secondary minerals. Since our goal was to investigate microbial enrichment of a variety of igneous phases, using one osmotically driven pump for each mineral sample and its control was unworkable in the space available in the borehole. The "in series" design also has the benefit of ensuring that all minerals in the "control" and "experimental" cells experience the same volume of water.

[8] All minerals and glasses were autoclaved before being placed in the chambers. Pairs of flow cells (1-2, 3-4, and 5-6) were designated "experimental" (flow cells 1, 3, and 5) and "control" (flow cells 2, 4, and 6). The "experimental" and "control" of each pair had the same sequence of minerals. The "experimental" flow cells were exposed to ambient borehole water while the water entering the "controls" was sterilized using 0.2 micron filters. Each "experimental/control" flow cell pair was connected to an osmotically driven pump [Jannasch et al., 2004]. The flow cell pairs were spaced $\sim 3 \mathrm{~m}$ apart between 275 to $287 \mathrm{mbsf}$ and were placed in Hole 1301A on July 20, 2004, inside slotted steel casing near the base of the borehole observatory [Fisher et al., 2005b].

[9] The flow cells were opened and the mineral chambers were emptied immediately upon being recovered and brought aboard R/V Atlantis in August 2008. Aseptic techniques were used in all procedures to avoid contamination from airborne or shipboard microbes. Minerals were separated into aliquots; some were used to inoculate media aboard ship, and the remainder stored at $4{ }^{\circ} \mathrm{C}$ and $-40^{\circ} \mathrm{C}$. Mineral suspensions used to inoculate iron oxidizer/ iron reducer media on board R/V Atlantis were stored at $4^{\circ} \mathrm{C}$ and used for organotrophic enrichments and cell counts upon return to the laboratory ( $\sim 1$ week later).

\subsection{Enrichments for Thermophilic Iron Oxidizers and Iron Reducers}

[10] The enrichment media described below were inoculated aboard ship within four hours of recovery. Enrichments for iron oxidizers and iron reducers 


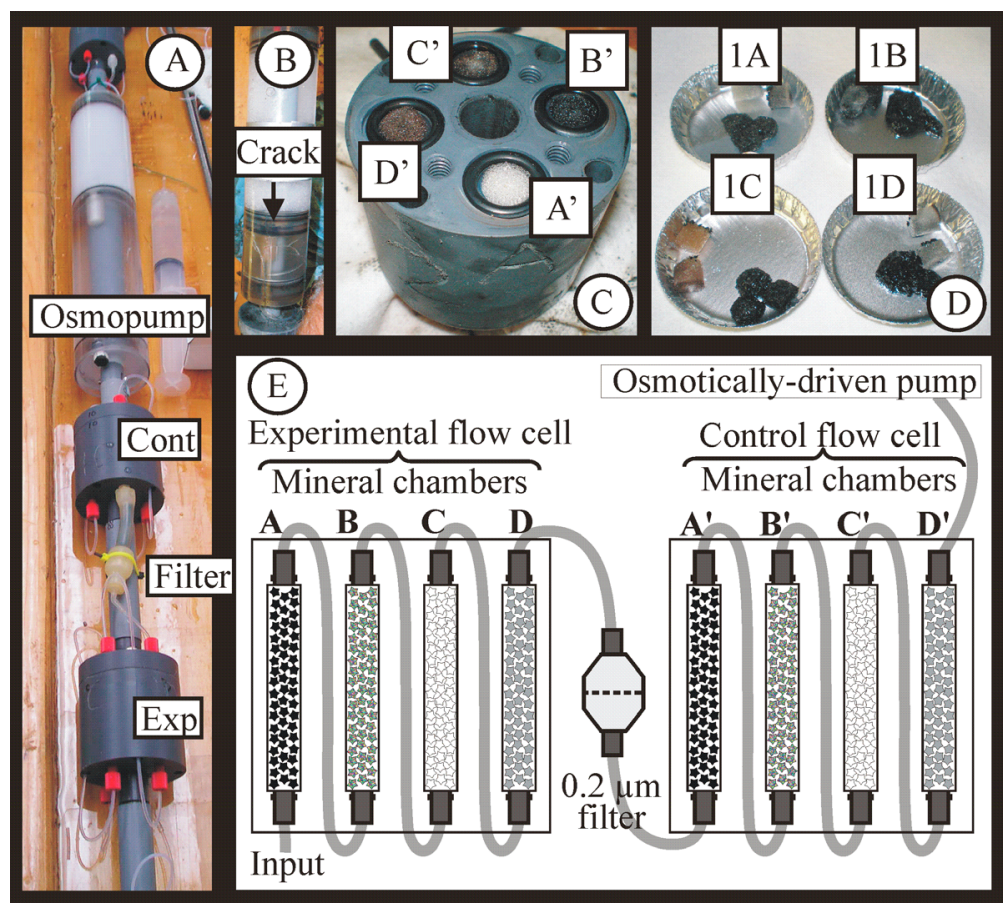

Figure 2. (a) Hole 1301A string organization of one flow cell pair with an osmotically driven pump shown prior to deployment (modified from Fisher et al. [2005a]). (b) One of the cracked osmotically driven pumps, with $\mathrm{NaCl}$ solution remaining. (c) Flow cell 2 opened to show the four chamber outlets (top side) with black O-rings and retaining sponges. Borehole water entered through the bottom of chamber A, exited through the top of chamber A (visible with white sponge), then entered the other three chambers in succession from bottom to top, eventually exiting the flow cell out of the top of chamber D. Sponge darkening in chambers B, C, and D is likely due to iron sulfide precipitates from $\mathrm{H}_{2} \mathrm{~S}$ reacting with the iron from olivines. Chamber A contained an iron-poor mineral. (d) Mineral sands and retaining sponges recovered from flow cell 1. Discoloration of the sponges is visible. (e) Diagram depicting one pair of flow cells (one "experimental" and one "control"). Each flow cell chamber contained one mineral (A, B, C, or D). A', B', C', and D' minerals from the "control" flow cells were the same as A, B, C, and D. The minerals contained in each chamber are listed in Table 1.

were prepared in Hungate tubes using $10 \mathrm{ml}$ of pH 8 Artificial Sea Water (ASW) medium modified from Emerson et al. [2007]. The ASW medium contained: $470 \mathrm{mM} \mathrm{NaCl} ; 20 \mathrm{mM} \mathrm{Na}_{2} \mathrm{SO}_{4} ; 1.5 \mathrm{mM}$ $\mathrm{KCl} ; 1 \mathrm{mM} \mathrm{NaHCO} 3 ; 1 \mathrm{mM} \mathrm{MgCl} 2 ; 0.5 \mathrm{mM}$ $\mathrm{NH}_{4} \mathrm{Cl} ; 0.37 \mathrm{mM} \mathrm{K} \mathrm{HPO}_{4} ; 20 \mathrm{~mL} / \mathrm{L}$ Wolfe trace elements mix; and $1 \mathrm{ml} / \mathrm{L}$ Wolfe vitamins mix. The Wolfe trace elements mixture contained: $12 \mathrm{mM}$ $\mathrm{Mg}^{2+} ; 12 \mathrm{mM} \mathrm{SO}_{4}^{2-} ; 0.25 \mathrm{mM} \mathrm{Mn}^{2+} ; 0.37 \mathrm{mM} \mathrm{Fe}^{3+}$;
$0.42 \mathrm{mM} \mathrm{Co}^{2+} ; 0.68 \mathrm{mM} \mathrm{Ca}^{2+} ; 0.37 \mathrm{mM} \mathrm{Zn}^{2+}$; $0.118 \mathrm{mM} \mathrm{Cu}^{2+} ; 21 \mu \mathrm{M} \mathrm{Al}^{3+} ; 0.021 \mathrm{mM} \mathrm{K}^{+}$; $0.16 \mathrm{mM} \mathrm{BO}_{3}^{3-}$; and $41 \mu \mathrm{M} \mathrm{Mo}^{6+}$. The Wolfe vitamins mixture contained $5 \mu \mathrm{g} / \mathrm{mL} \mathrm{p}$-aminobenzoic acid; $5 \mu \mathrm{g} / \mathrm{mL}$ biotin; $5 \mu \mathrm{g} / \mathrm{mL}$ cyanocobalamin; $5 \mu \mathrm{g} / \mathrm{mL}$ folic acid; $100 \mu \mathrm{g} / \mathrm{mL}$ i-inositol; $100 \mu \mathrm{g} / \mathrm{mL}$ nicotinic acid; $100 \mu \mathrm{g} / \mathrm{mL}$ pyridoxine; $100 \mu \mathrm{g} / \mathrm{mL}$ panthotenic acid; $100 \mu \mathrm{g} / \mathrm{mL}$ riboflavin and $1 \mu \mathrm{g} / \mathrm{mL}$ thiamine. Iron oxidizer enrichments contained $1 \mathrm{~g}$

Table 1. Mineral and Glass Placement in the Flow Cells Incubated in Hole $1301 \mathrm{~A}^{\mathrm{a}}$

\begin{tabular}{|c|c|c|c|c|}
\hline \multirow{2}{*}{$\begin{array}{l}\text { Flow Cell } \\
\text { Number }\end{array}$} & \multicolumn{4}{|c|}{ Mineral Chamber } \\
\hline & $\mathrm{A}$ and $\mathrm{A}^{\prime}$ & $\mathrm{B}$ and $\mathrm{B}^{\prime}$ & $\mathrm{C}$ and $\mathrm{C}^{\prime}$ & $\mathrm{D}$ and $\mathrm{D}^{\prime}$ \\
\hline $\begin{array}{l}1 \text { and } 2 \\
3 \text { and } 4 \\
5 \text { and } 6\end{array}$ & $\begin{array}{c}\text { forsterite } \\
\left(\mathrm{Fo}_{100}\right) \mathrm{Mg}_{2} \mathrm{SiO}_{4} \\
\text { basalt glass } \\
\text { anorthite } \mathrm{CaAl}_{2} \mathrm{Si}_{2} \mathrm{O}_{8}\end{array}$ & $\begin{array}{c}\text { olivine } \\
\qquad \begin{array}{c}\left(\mathrm{Fo}_{90}\right) \\
\mathrm{Mg}_{1.8} \mathrm{Fe}_{0.2} \mathrm{SiO}_{4} \\
\text { obsidian }\end{array} \\
\text { bytownite } \mathrm{Na}_{0.2} \mathrm{Ca}_{0.8} \mathrm{Al}_{1.8} \mathrm{Si}_{2.2} \mathrm{O}_{8}\end{array}$ & $\begin{array}{c}\text { fayalite } \\
\left(\mathrm{Fo}_{0}\right) \mathrm{Fe}_{2} \mathrm{SiO}_{4} \\
\text { augite }(\mathrm{Mg}, \mathrm{Fe}) \mathrm{CaSiO}_{6} \\
\text { orthoclase } \mathrm{KAlSi}_{3} \mathrm{O}_{8}\end{array}$ & $\begin{array}{c}\text { hornblende } \\
\mathrm{Ca}_{2}(\mathrm{Mg}, \mathrm{Fe})_{4} \mathrm{Al}\left(\mathrm{Si}_{7} \mathrm{Al}\right) \mathrm{O}_{22}(\mathrm{OH})_{2} \\
\text { diopside } \mathrm{MgCaSiO}_{6} \\
\text { apatite } \mathrm{Ca}_{5}\left(\mathrm{PO}_{4}\right)_{3} \mathrm{OH}\end{array}$ \\
\hline
\end{tabular}

${ }^{\mathrm{a}}$ Borehole water was pumped through the flow cell mineral chambers in sequence from $\mathrm{A}$ through $\mathrm{D}$, then $\mathrm{A}^{\prime}$ through $\mathrm{D}^{\prime}$ as shown in Figure 2 for each flow cell pair. Mineral generic chemical formulas are given. Glasses do not have fixed formulas. Forsterite notation is given for olivines. 
of $\mathrm{Fo}_{90}$ olivine as the reductant and $1 \% \mathrm{O}_{2}$ as the oxidant. Iron reducer enrichments were based on media described previously [Kashefi et al., 2002] and contained $10 \mathrm{mM}$ ferric chloride as the oxidant, with $5 \mathrm{mM}$ acetate and $5 \mathrm{mM}$ lactate as reductants. The iron reducer enrichments were incubated under a $\mathrm{N}_{2}$ atmosphere containing an initial concentration of $\sim 1.6 \% \mathrm{O}_{2}$. All enrichments were inoculated with $100 \mu \mathrm{L}$ of "experimental" mineral suspensions from tubes containing $50 \mathrm{mg}$ mineral sand and $250 \mu \mathrm{L} 0.1$ micron-filtered sterile seawater, then immediately placed into a $55^{\circ} \mathrm{C}$ incubator. After transfer to the laboratory, all irondissimilating microbial enrichments were incubated at $55^{\circ} \mathrm{C}$ for up to 6 weeks. Growth was monitored over the incubation period using DAPI staining of microbes in suspension after vigorous vortexing for $15 \mathrm{~min}$ and epifluorescent microscopic counting [Bennett et al., 2006].

\subsection{Isolation and Identification of Aerobic Oligotrophs}

[11] Approximately $1 \mathrm{~g}$ of each mineral specimen was aseptically recovered from each chamber of the flow cells aboard ship and stored at $4{ }^{\circ} \mathrm{C}$ until plated in the laboratory (approximately 1 week later). Measured amounts of minerals and filter-sterilized seawater were mixed, vortexed vigorously for $15 \mathrm{~min}$, then immediately used to produce serial dilutions for culturing oligotrophs on plates and total direct counting. The immediate transfer ensured that microbes immobilized on very fine suspended mineral particles were also included in the serial dilution. Serial dilutions were plated in triplicate on Marine R2A (MR2A) media (Difco R2A agar Catalog 218263 plus $27.5 \mathrm{~g} / \mathrm{L} \mathrm{NaCl}$ ), a low-organic solid media for isolating oligotrophs. MR2A plates were incubated at $55^{\circ} \mathrm{C}$ and $25^{\circ} \mathrm{C}$ for up to one week. The Colony Forming Units (CFUs) were counted and averaged across triplicates. Dilutions containing between 30 and 500 colonies were used for calculating $\mathrm{CFU} / \mathrm{mL}$ and then $\mathrm{CFU} / \mathrm{g}$ of mineral.

[12] Eight colonies with dissimilar morphology were selected per mineral for DNA sequencing. Isolates were named with numbers corresponding to the flow cell number and letters corresponding to the mineral chamber (Table 1). Plates from basalt glass and apatite were subsequently lost due to fungal contamination during later transfers and were not included in DNA analysis. Libraries of isolated colonies were saved $\left(-80^{\circ} \mathrm{C}\right.$ in $50 \%$ glycerol). For phylotyping, the isolated colonies were scraped from plates and the genomic DNA (gDNA) was extracted in $99^{\circ} \mathrm{C} \mathrm{TE}$ buffer for 10 min [Cook and Meyers, 2003; Mazza et al., 2003]. The concentration of gDNA was quantified with a NanoDrop 1000 spectrophotometer. Supernatants containing DNA were used as a DNA template in a Polymerase Chain Reaction (PCR) targeting the 16S rRNA gene using either the bacterial 8F (5'AGAGTTTGATCCTGGCTCAG) or archaeal 4F (5'TCCGGTTGATCCTGGCRG) primers; and 1492R (5'GGTTACCTTGTTACGACTT) [Baker et al., 2003]. Only a few microbial isolates $(<5 \%)$ having very low gDNA yields were not successfully amplified with this combination of primers. All PCR amplifications used a PCR kit (Fermentas) and a GeneAmp 2400 thermocycler (Perkin Elmer), and the following conditions $\left(95^{\circ} \mathrm{C}\right.$ for $3 \mathrm{~min}, 40$ cycles of: $95^{\circ} \mathrm{C}$ for $30 \mathrm{~s}, 50^{\circ} \mathrm{C}$ for $30 \mathrm{~s}$, and $72^{\circ} \mathrm{C}$ for $1 \mathrm{~min}$, then a final $72^{\circ} \mathrm{C}$ for $5 \mathrm{~min}$ ). The PCR products were verified by agarose gel electrophoresis, cleaned by using a PCR cleanup kit (Qiagen) and sequenced using an ABI 3130xl sequencer at the Oregon Health Sciences University DNA Core Facility.

[13] Sequence files were trimmed to between 300 and 350 nucleotides depending on sequence quality. Trimmed sequences were aligned and clustered into operational taxonomic units (OTU) at 97\% sequence similarity using tools available through the Ribosomal Database Project (RDP) [Cole et al., 2009]. Representative sequences of each bacterial OTU were chosen to receive nearly full-length $16 \mathrm{~S}$ rRNA gene sequencing using the primers $5 \mathrm{~F}, 515 \mathrm{~F}$, and $1492 R$. Sequence fragments were manually aligned in MEGA4 and all representative sequences were aligned and trimmed to 1269 nucleotides. Representative bacterial sequences were then imported into ARB [Ludwig et al., 2004], aligned according to secondary structure constraints, and added to the Silva-96 reference tree [Pruesse et al., 2007]. 16S rRNA gene sequences of cultured organisms closely related to our isolates and those of similar organisms from ocean crust habitats were selected and all sequences were imported into and aligned with MEGA4 [Tamura et al., 2007]. Phylogenetic analysis was conducted in both ARB and MEGA4 on only unambiguous nucleotide positions (636 bp). A phylogenetic tree was generated using the neighborjoining method [Saitou and Nei, 1987] with 500 bootstrap replications in MEGA4. Tree topologies from MEGA4 were identical with those from ARB.

\subsection{Fixing Cells From Mineral Surfaces}

[14] Mineral samples were fixed on board $\mathrm{R} / \mathrm{V}$ Atlantis following procedures described previously [Bennett et al., 2006]. Immediately after opening 
the flow cells, approximately $250 \mathrm{mg}$ of mineral samples were placed in sterile $1.5 \mathrm{~mL}$ tubes and rinsed gently with 1x Phosphate-Buffered Saline (PBS) by inverting very gently and slowly. The supernatants were removed with a pipette and saved in $1.5 \mathrm{~mL}$ microcentrifuge tubes. The remaining minerals were prepared for staining by mixing 1 volume of the sample with 3 volumes ice-cold $4 \%$ paraformaldehyde (PFA). Samples were allowed to fix at $4^{\circ} \mathrm{C}$ for $12 \mathrm{~h}$. After fixing, the supernatant was removed and saved again, then 4 volumes $1 \mathrm{x}$ PBS was added down the inside of the tube to leave crystals undisturbed. The fluid in the tubes was gently mixed by pipetting up and down. This washing step was repeated three times. Samples were resuspended in 1 volume $1 \mathrm{x}$ PBS and an additional 1 volume of ice-cold $96 \%$ (v/v) ethanol was added to the tubes. All samples were placed at $-20^{\circ} \mathrm{C}$ until stained in the laboratory. Cells from $10 \mu \mathrm{L}$ aliquots of removed fixative, washes, and the fixed mineral samples were mixed with $90 \mu \mathrm{L}$ of a $5 \mu \mathrm{g} / \mathrm{mL}$ DAPI (4', 6-diamidino-2-phenylindole) solution in PBS and incubated for 5 min [Bennett et al., 2006]. Cells were visualized with an epifluorescent microscope (Carl Zeiss, Axioscope).

\subsection{DAPI Staining of Cells From Mineral Specimens}

[15] Methods of counting cells on minerals from environmental samples were followed as described previously [Bennett et al., 2006]. To obtain total cell counts, $10 \mu \mathrm{L}$ aliquots of the vortexed serial dilutions were suspended in $90 \mu \mathrm{L}$ of filter-sterilized 1x (PBS) buffer. Aliquots of this suspension $(10 \mu \mathrm{L})$ were mixed with $90 \mu \mathrm{L}$ of DAPI-PFA staining solution ( $5 \mu \mathrm{g} / \mathrm{mL}$ of 4', 6-diamidino-2-phenylindole solution in PBS with 4\% paraformaldehyde) and incubated for $5 \mathrm{~min}$ [Bennett et al., 2006]. One $\mathrm{ml}$ of PBS was added to each cell suspension and the mixtures were transferred to black polycarbonate $0.2 \mu \mathrm{m}$ filters (Poretics), and washed with $2 \mathrm{~mL}$ of PBS buffer. Cell numbers were counted using an epifluorescent microscope (Carl Zeiss, Axioscope) then expressed in cells $\mathrm{g}$ mineral ${ }^{-1}$.

\subsection{Petrographic Thin Sections}

[16] Samples were placed in sterile metal weigh dishes then $100 \mu \mathrm{L}$ of DAPI solution (see section 2.6) was added for each $1 \mathrm{~mL}$ of liquid that remained with the mineral samples after transfer from the flow cells. Samples were kept in the dark for all subsequent steps to avoid photodegradation of DAPI stain. Samples were incubated at room temperature for $10 \mathrm{~min}$, gently swirling a few times to mix. One volume of $95 \%$ ethanol was added to fix cells to minerals and incubated for $5 \mathrm{~min}$. One volume of $\mathrm{ddH}_{2} \mathrm{O}$ was added and swirled gently to mix, and then the liquid was decanted. Samples were rinsed with 5 volumes $\mathrm{ddH}_{2} \mathrm{O}$ twice more and decanted again. A sterile pipette was used to remove any remaining excess liquid. Samples were allowed to dry in a warm, dark, oven overnight covered with aluminum foil. Samples were kept in foil-wrapped $1.5 \mathrm{~mL}$ tubes until returned to the lab. Petrographic thin sections of mineral sands were prepared without heating at OSU using Epo-Tek 301 low-fluorescence resin. Thin sections were viewed under light and fluorescent microscopy to visualize cells and search for mineral weathering patterns.

\subsection{Physiological Screening of Organotrophs for Iron Oxidation and Nitrate Reduction}

[17] All phylotypes were evaluated for the ability to reduce nitrate and nitrite and to oxidize Fe(II). For the nitrate reduction test, we prepared a marine $10 \mathrm{mM}$ nitrate broth (DIFCO Catalog 226810 plus $470 \mathrm{mM} \mathrm{NaCl}$ ) in culture tubes containing an inverted Durham tube to capture any gas produced from denitrification. After 5 days incubation at $30^{\circ} \mathrm{C}$, cultures were analyzed for evidence of denitrification, and nitrate and nitrite reduction as described previously [Leboffe and Pierce, 2005]. Strains that produced gas while growing in nitrate broth were also tested for carbohydrate fermentation using Triple Sugar Iron Agar [Leboffe and Pierce, 2005]. Iron oxidation was verified using gradient tubes with a $30 \mathrm{mM} \mathrm{FeCO} 32 \%$ agar plug at the bottom of the tube. The $0.5 \%$ soft agar overlay contained the marine mineral medium described above supplemented with $30 \mathrm{mM} \mathrm{NO}_{3}^{-}$as an alternate electron acceptor and $2 \mathrm{mg} / \mathrm{L}$ resazurin redox indicator. Tubes were incubated at $25^{\circ} \mathrm{C}$ for four days. Iron oxidation was confirmed by the presence of a discrete growth band in the soft agar gel that was not present in the negative control. The increased abundance of microbes in the bands was verified by microscopy. Strains that did not produce a growth band with cells or remained identical to the uninoculated tubes were assumed to be negative for iron oxidation capabilities.

\subsection{Growth of Selected Strains on Olivine and Nitrate}

[18] Four strains related to known iron oxidizers were chosen to determine their ability to grow on 
olivine in a mineral medium containing nitrate as the oxidant. One gram of washed $\mathrm{Fo}_{90}$ olivine sand was placed in Hungate tubes containing $6 \mathrm{ml}$ of pH 8 ASW medium. ASW medium content was as described in section 2.3, except for the following additions: $10 \mathrm{mM}$ total $\mathrm{NaHCO}_{3}$ and $\mathrm{PO}_{4}^{3-}$, $10 \mathrm{mM} \mathrm{NO}_{3}^{-}, 1 \mathrm{mM}$ acetate, and $3 \mathrm{mM} \mathrm{L}$-cysteine hydrochloride as a reducing agent. Tubes were sealed and crimped with $1 \mathrm{~cm}$ butyl stoppers and bubbled with $\mathrm{N}_{2}$ gas containing $1.6 \% \mathrm{O}_{2}$. After autoclaving, tubes were inoculated with either Nitratireductor strain 3d.4, Halomonas strain 1c.1, Marinobacter strain 1c.10, Pseudomonas strain 1b.2, or freshwater aquarium soil enrichments. Prior to inoculation, all organisms were grown in marine $\mathrm{R} 2 \mathrm{~B}$ for 5 days at $25^{\circ} \mathrm{C}$ then centrifuged at $1250 \mathrm{rpm}$ for $10 \mathrm{~min}$. Media was removed with a pipette and cell pellets were washed with $1 \mathrm{~mL}$ ASW medium. $0.5 \mathrm{~mL}$ of this suspension was injected into the culture tubes using a $1 \mathrm{~mL}$ syringe. Tubes were incubated at $30^{\circ} \mathrm{C}$ for up to one month. Cell counts were taken on days 5 and 22 using a microscopic counting chamber.

\subsection{Marinobacter Strain $3 \mathrm{~d} .6 \mathrm{O}_{2}$ Respiration and Fe(III) Reduction on Olivines}

[19] Marinobacter strain 3d.6 cells were grown for 5 days at $25^{\circ} \mathrm{C}$ in marine R2B medium supplemented with $1 \mathrm{mM} \mathrm{FeSO}_{4}$. Cells were pelleted by centrifugation and washed in ASW. Cell suspensions were injected into sterilized $140 \mathrm{~mL}$ sealed and crimped culture jars containing $1 \mathrm{~g}$ washed $\mathrm{Fo}_{90}$ or $\mathrm{Fo}_{0}$ olivine sand and $p H 7.3 \mathrm{ASW}$ medium under $21 \% \quad \mathrm{O}_{2}$ atmosphere. Oxygen evolution was monitored weekly for 8 weeks, then again at 22 weeks. $\mathrm{O}_{2}$ concentration in the head space was measured by gas chromatography using an SRI 310C instrument, a Molecular sieve column, and a TCD detector. The gas pressure was measured with an Omega pressure meter (Omega Engineering, Inc. $\mathrm{Ct}$ ).

[20] For Fe(III) reduction testing, media were prepared as above except the jars were flushed with $\mathrm{N}_{2}$ gas containing $1.6 \% \mathrm{O}_{2}$. A mix of LASP ( $\mathrm{Na}$ lactate, $\mathrm{Na}$ pyruvate, $\mathrm{Na}$ acetate, and $\mathrm{Na}$ succinate) ( $5 \mathrm{mM}$ final concentration) were added as potential reductants to reduce $\mathrm{Fe}(\mathrm{III})$ on the surface of olivine crystals. Jars were incubated at $30^{\circ} \mathrm{C}$ for 5 weeks, and each medium was analyzed by high-performance liquid chromatography (HPLC) weekly for changes in LASP. HPLC was performed with a DYNAMAX SD-300 instrument with ESA UV detector and REZEX $8 \mu$ organic acids column.

\section{Results}

\subsection{Conditions of Hole 1301A}

[21] Data retrieved from borehole instruments and reported by Wheat et al. [2010] indicated that the temperature in the borehole rose steadily from $\sim 4^{\circ} \mathrm{C}$ to $\sim 30^{\circ} \mathrm{C}$ over the first 3 years of the experiment. During this time, bottom water was drawn down the borehole into the formation because the CORK observatory was not sealed. During this time, bottom water became slightly altered as it flowed down the borehole. At the beginning of the fourth year, flow down the hole stopped and overpressured formation fluid flowed into and up the borehole, causing the borehole temperature to rise significantly during a one week period $(9 / 3 / 07-9 / 10 / 07)$ to $\sim 64^{\circ} \mathrm{C}$, where it remained until our samples were recovered in August 2008. During this 1 week temperature increase, the altered seawater was replaced with formation water that has similar composition to borehole water from Baby Bare springs and nearby ODP site 1026B [Cowen et al., 2003]. OsmoSamplers placed in Hole 1301A provided a continuous record of borehole chemistry throughout the deployment [Wheat et al., 2010], showing that nitrate concentration decreased during the first 2 years from $>30 \mu \mathrm{M}$ to near $0 \mu \mathrm{M}$, and ammonium increased in the last year from near $0 \mu \mathrm{M}$ to around $800 \mu \mathrm{M}$ [Wheat et al., 2010; Orcutt et al., 2010b].

\subsection{Flow Cell Condition After Recovery}

[22] Upon recovery of the instrument string in August 2008, all osmotically driven pump housings were cracked, yet they still continued to function [Wheat et al., 2010]. Water flow through the chambers over the period of the experiment was confirmed by the distribution of the dark precipitate on the retaining sponges (Figure 2). Although we did not measure the pump rates directly, they were calibrated prior to deployment. Using the calibrated pump rate, $92 \mathrm{~mL}$ of borehole fluid (slightly altered seawater) was pumped through the flow cells during the initial 3 years of deployment. This volume was about 10 times that of the liquid in the eight chambers in an "experimental/control" pair, connecting tubes, and filter holder that were connected to each osmotic pump. During the final year of deployment, additional borehole fluids (hydrothermal waters) would have been pumped 


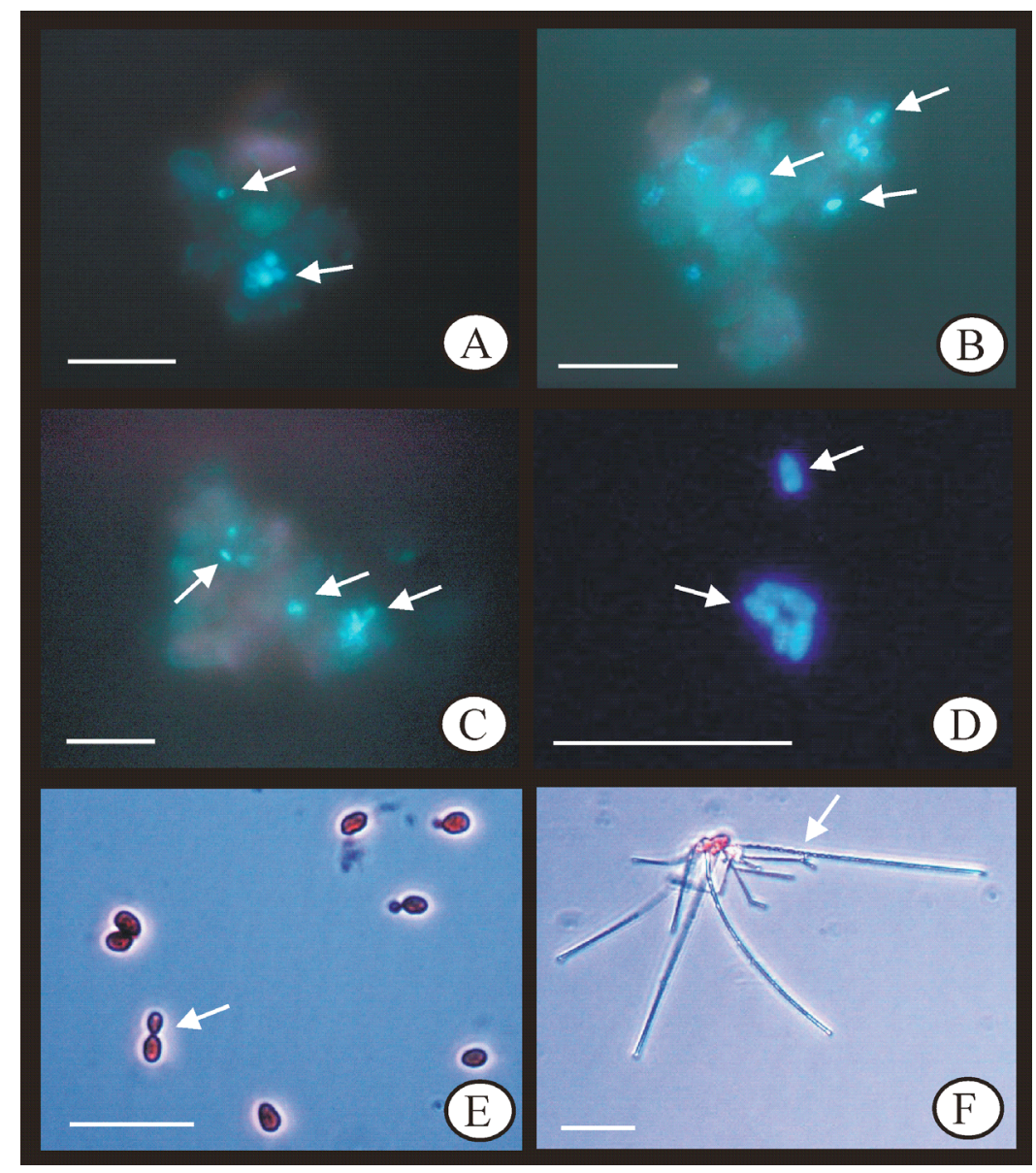

Figure 3. (a-c) DAPI staining of PFA-fixed cells (arrows) attached to mineral particles from fayalite (Figure 3a), olivine (Figure 3b), and basalt (Figure 3c). (d) DAPI-stained cells visualized during cell counting from vortexed fayalite minerals. (e) A $1000 \times$ phase contrast image of marine oligotrophic broth culture of microfungi (Rhodotorula sp.) isolated from minerals incubated in Hole 1301A. Arrow indicates budding cells. (f) A 1000× phase contrast image of possible microbial structure in suspension of incubated basalt made with sterile seawater. These structures appear similar to twisted stalks (arrow) that are commonly produced by iron-oxidizing microbes. Bars equal $10 \mu \mathrm{M}$.

through the cells at a higher rate. In a parallel experiment in the same borehole, a maximum of $600 \mathrm{ml}$ was pumped through a fluid sampler during the final year of the deployment [Wheat et al., 2010]. This faster pump rate is in part related to the increase in temperature and the alteration of the membrane as it aged in this warm, reducing environment. The $0.2 \mu \mathrm{m}$ filter membranes between "experimental" and "control" flow cells appeared to be intact, but may not have functioned with $100 \%$ efficiency.

\subsection{Visualizing and Counting Cells on Minerals}

[23] PFA-fixed cells from mineral surfaces, mineral washes, and removed fixative solution were visualized with epifluorescent microscopy. In all sample types, cells were attached to mineral particles and not free floating. In general, mineral particles (either primary or secondary) harbored multiple cells (Figures 3a-3c). The most common cell morphology was a rod shape, however many cells were ovoid or cocci. No filamentous organisms were observed in the fixed samples. Phase contrast images of nonfixed mineral suspensions used to create microbial enrichments revealed a wide diversity of cell types, including large $(\sim 5 \mu \mathrm{M})$ ovoid gliding cells, rodshaped microbes, and other presumed microbial structures or secondary minerals (Figure 3f).

[24] Total cell counts by DAPI staining and microscopy (Table 2, Figure 3d) were achieved for both the "experimental" and "control" mineral groups. For each mineral specimen, the cell counts for "experimental" minerals were always larger (2-25 times) than on "control" minerals. Cell counts from the "experimental" flow cells were highest for 
Table 2. Total Cell Counts (From DAPI Staining and Microscopy) From Minerals and Glasses Incubated in Hole $1301 \mathrm{~A}^{\mathrm{a}}$

\begin{tabular}{|c|c|c|c|c|}
\hline Mineral/Glass & $\begin{array}{l}\text { Experimental Flow } \\
\text { Cell Chamber }\end{array}$ & $\begin{array}{c}\text { Experimental Total } \\
\text { Cell Counts } \\
\left(10^{6} \text { cells g mineral }^{-1}\right)\end{array}$ & $\begin{array}{l}\text { Control Flow } \\
\text { Cell Chamber }\end{array}$ & $\begin{array}{l}\text { Control Total Cell Counts } \\
\left(10^{6} \text { cells } g \text { mineral }^{-1}\right)\end{array}$ \\
\hline Forsterite & $1 \mathrm{~A}$ & $140 \pm 21$ & $2 \mathrm{~A}^{\prime}$ & $5.0 \pm 1$ \\
\hline Olivine & $1 \mathrm{~B}$ & $390 \pm 19$ & $2 \mathrm{~B}^{\prime}$ & $39 \pm 6$ \\
\hline Fayalite & $1 \mathrm{C}$ & $280 \pm 48$ & $2 \mathrm{C}^{\prime}$ & $19 \pm 1$ \\
\hline Hornblende & $1 \mathrm{D}$ & $150 \pm 2$ & $2 \mathrm{D}^{\prime}$ & $60 \pm 3$ \\
\hline Basalt & $3 \mathrm{~A}$ & $88 \pm 7$ & $4 \mathrm{~A}^{\prime}$ & $3.0 \pm 1$ \\
\hline Obsidian & $3 \mathrm{~B}$ & $92 \pm 7$ & $4 \mathrm{~B}^{\prime}$ & $27 \pm 2$ \\
\hline Augite & $3 \mathrm{C}$ & $91 \pm 2$ & $4 C^{\prime}$ & $8.0 \pm 2$ \\
\hline Diopside & $3 \mathrm{D}$ & $46 \pm 11$ & $4 \mathrm{D}^{\prime}$ & $27 \pm 3$ \\
\hline Anorthite & $5 \mathrm{~A}$ & $50 \pm 14$ & $6 \mathrm{~A}^{\prime}$ & $6.0 \pm 2$ \\
\hline Bytownite & $5 B$ & $23 \pm 4$ & $6 \mathrm{~B}^{\prime}$ & $3.0 \pm 1$ \\
\hline K-feldspar & $5 \mathrm{C}$ & $39 \pm 10$ & $6 C^{\prime}$ & $12 \pm 1$ \\
\hline Apatite & $5 \mathrm{D}$ & $100 \pm 6$ & $6 \mathrm{D}^{\prime}$ & $9.0 \pm 0$ \\
\hline
\end{tabular}

${ }^{\mathrm{a}}$ The \pm values represent one standard deviation from triplicates.

the iron-bearing olivines ( $\mathrm{Fo}_{90}$ olivine and fayalite, Table 2), with $45 \%$ of the total cells counted from all minerals originating from these two minerals.

\subsection{Isolating and Counting Microorganisms}

[25] CFU counts for each mineral incubated in Hole 1301A show a significantly higher relative abundance of mesophilic oligotrophs (Table 3) on $\mathrm{Fe}(\mathrm{II})$-containing minerals. $\mathrm{Fo}_{90}$ olivine and fayalite had the largest numbers of isolated oligotrophic mesophiles on mineral surfaces, with forsterite, apatite, and anorthite next highest in abundance. CFU counts for "experimental" thermophilic aerobic oligotrophs (Table 3) showed that olivine and fayalite were the only minerals containing these organisms, with trace amounts found on hornblende. The organotrophic oligotrophs (defined as microbes growing on low-organic media such as R2A) growing in mesophilic conditions were a very small fraction of the total microbial community (quantified by direct counting). On the other hand, the thermophilic oligotrophs were a larger fraction of the total community in olivine (25\%) and fayalite (100\%), and no thermophiles were found in nonolivine mineral chambers. No growth was observed in the $55^{\circ} \mathrm{C}$ iron dissimilatory enrichments over a 6 week period.

\subsection{Identification of Aerobic Oligotrophs}

[26] A total of 84 aerobic mesophilic oligotrophs isolated from all "experimental" minerals were characterized by DNA sequencing. These sequences belonged to only 9 phylotypes (Table 4) distributed fairly homogenously across all minerals. The most commonly isolated organisms were related to the genera Alcanivorax, Marinobacter and Halomonas,

Table 3. Abundance of Culturable Oligotrophs (Aerobes) From Minerals and Glasses Incubated in "Experimental” Flow Cells 1, 3, and 5 From Hole 1301A

\begin{tabular}{|c|c|c|c|c|}
\hline Mineral/Glass & $\begin{array}{l}\text { Abundance of } \\
\text { Mesophilic Oligotrophs } \\
\left(10^{6} \text { CFU g mineral }{ }^{-1}\right)\end{array}$ & $\begin{array}{l}\text { Abundance of } \\
\text { Mesophilic Oligotrophs } \\
\text { Relative to the } \\
\text { Total Cell Counts } \\
\text { (in } \% \pm 0.5 \% \text { ) }\end{array}$ & $\begin{array}{c}\text { Abundance of } \\
\text { Thermophilic Oligotrophs } \\
\left(10^{6} \text { CFU g mineral }{ }^{-1}\right)\end{array}$ & $\begin{array}{c}\text { Abundance of } \\
\text { Thermophilic Oligotrophs } \\
\text { Relative to the } \\
\text { Total Cell Counts } \\
\text { (in } \% \pm 0.5 \%)\end{array}$ \\
\hline Forsterite & 6.0 & 4 & 0.0 & 0 \\
\hline Olivine & 8.0 & 2 & 95 & 25 \\
\hline Fayalite & 8.0 & 3 & 290 & $\sim 100$ \\
\hline Hornblende & 1.0 & 1 & 0.003 & 0.002 \\
\hline Basalt glass & 2.0 & 2 & 0.0 & 0 \\
\hline Obsidian & 3.0 & 3 & 0.0 & 0 \\
\hline Augite & 2.0 & 2 & 0.0 & 0 \\
\hline Diopside & 0.3 & 1 & 0.0 & 0 \\
\hline Anorthite & 4.0 & 9 & 0.0 & 0 \\
\hline Bytownite & 3.0 & 13 & 0.0 & 0 \\
\hline K-feldspar & 2.0 & 6 & 0.0 & 0 \\
\hline Apatite & 5.0 & 1 & 0.0 & 0 \\
\hline
\end{tabular}


Table 4. Most Common Mesophilic Organotrophic Phylotypes Isolated From Flow Cell Minerals Incubated in $1301 \mathrm{~A}^{\mathrm{a}}$

\begin{tabular}{lcc}
\hline \multicolumn{1}{c}{ Phylogenetic Group } & Phylotype & Habitat of Closest Sequence Relative \\
\hline$\gamma$-Proteobacteria & Alcanivorax & Deep sea Mediterranean sediment \\
& Halomonas & Marinobacter \\
& Pseudomonas & Ocean sediment \\
$\alpha$-Proteobacteria & Aurantimonas & Indian Ocean deep sea \\
& Nitratireductor & Intertidal sand biofilms \\
High GC Gram + Actinobacteria & Stappia & Deep Indian Ocean oil-contaminated water \\
Urediniomycetes (fungi) & Microbacterium & Marine biofilms \\
& Rhodotorula & Indian Ocean deep seawater column \\
\hline
\end{tabular}

${ }^{\text {a}}$ Habitats for $16 \mathrm{~S}$ rDNA sequence relatives are included.

all belonging to $\gamma$-Proteobacteria. Marinobacter isolates exhibited more than one colony morphology on MR2A simultaneously indicating more than one type was isolated. Three isolates were most closely related to the yeast Rhodotorula. The DNA of Rhodotorula amplified with archaeal primers $4 \mathrm{~F}$ and $1492 \mathrm{R}$ and was identified by $18 \mathrm{~S}$ rDNA sequencing. The microfungi grew in colonies with pink pigmentation, cells were small $(3-5 \mu \mathrm{m})$ and spherical to ovoid in shape, and exhibited budding (Figure 3e). $\alpha$-Proteobacteria and Gram-positive Actinobacteria were also isolated in smaller numbers. A phylogenetic tree was constructed to show relatedness of isolated bacterial phylotypes to other known sequences or isolates and those from similar environments (Figure 4). Sequences obtained from this study were submitted to GenBank under the accession numbers HQ621830, and HQ427421HQ427430.

[27] The isolated thermophiles grew as very small round ivory colonies on MR2A media only. Gram staining revealed a large Gram-positive rod. We were able to retrieve only a small amount of biomass for DNA extraction and sequencing. Several attempts at amplifying the thermophile's DNA were unsuccessful with three pairs of 16S rDNA primers ( $8 \mathrm{~F}$ or ITSF with $1492 \mathrm{R}$ for bacteria, and $4 \mathrm{~F}$ and 1492R commonly used for archaea).

\subsection{DAPI-Stained Thin Sections}

[28] DAPI-stained thin sections of basalt glass and fayalite incubated in Hole 1301A (Figure 5) contained abundant cells in microfractures, however no clear evidence of bioweathering in association with these cells was found.

\subsection{Physiological Tests}

[29] All isolates are closely related to known nitrate reducers, and two isolates are related to known iron oxidizers (Marinobacter and Pseudomonas). $P$. stutzeri (the closest relative of the Pseudomonas isolates) and Marinobacter spp. have been shown to couple iron oxidation with nitrate reduction for growth [Edwards et al., 2003a; Straub et al., 1996]. We analyzed eleven strains, representing all nine identified phylotypes, for physiological characteristics relevant to growth on iron minerals. Testing for neutrophilic iron oxidation in $\mathrm{FeCO}_{3}$ gradient tubes revealed discrete growth bands containing abundant cells (Figure 6). We also tested the eleven strains for dissimilatory nitrate reduction, nitrite reduction, and denitrification capabilities. Ten of the eleven strains tested were able to oxidize iron and reduce nitrate to nitrite, seven were able to further reduce nitrite, six were capable of denitrification to $\mathrm{N}_{2}$ gas, and one could not perform any of the four physiologies tested (Table 5). Denitrification in nitrate broth was confirmed by the presence of gas in an inverted Durham tube, which was assumed to be $\mathrm{N}_{2}$ gas since all gas-producing strains tested negative for carbohydrate fermentation [Leboffe and Pierce, 2005]. We included three strains of Marinobacter in our physiological testing because they appeared to be different strains based on colony morphology. Marinobacter strain 1c.10 grew only at or very near the abiotic redox boundary in $\mathrm{FeCO}_{3}$ gradient tubes and was initially discounted as a potential iron oxidizer. This strain was determined to be a strict microaerophile when grown on MR2A gradient tubes containing resazurin as a redox indicator. Strain 1c.10 did not appear to reduce nitrate in nitrate reduction broth, however it was able to grow anaerobically on olivine in culture with nitrate as the oxidant and cysteine as a reducing agent (Figure 7a). More testing of this strain remains to be done to determine its full iron oxidation and nitrate reduction capabilities.

[30] Marinobacter strain 3d.6 consumed 5-11\% of the available oxygen in 22 weeks of incubation in olivine medium with $21 \% \mathrm{O}_{2}$ in the headspace (Figure 7a). Growth by olivine oxidation is indicated by $\mathrm{O}_{2}$ consumption with olivine as the only source of reducing power. Oxygen consumption in 


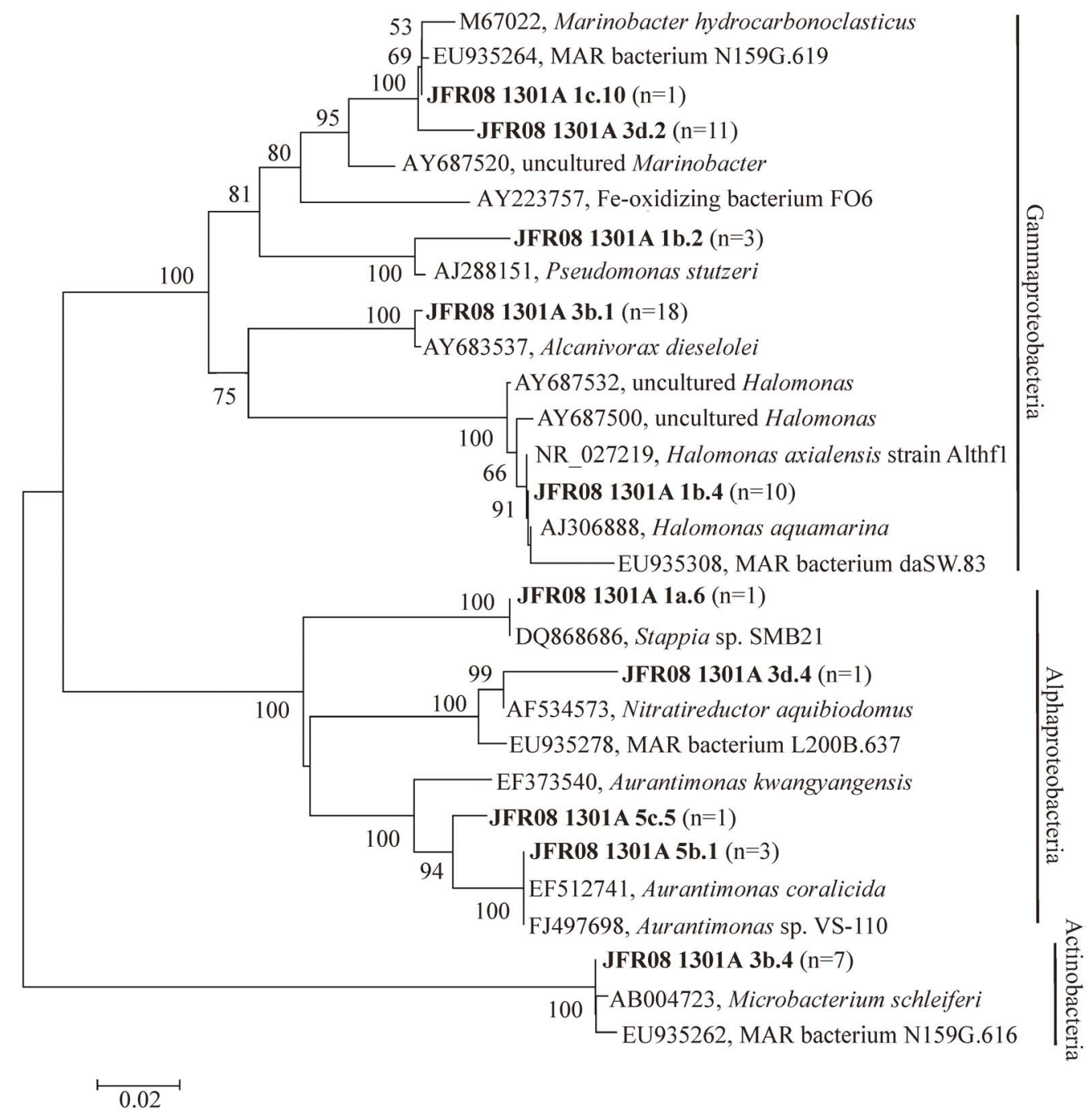

Figure 4. Phylogenetic analysis of isolates obtained from the minerals and glasses recovered from Hole 1301A in the JFR. Isolated organisms are shown in bold with the number of isolates obtained shown in parentheses. Isolates were named with numbers corresponding to the flow cell number and letters corresponding to the mineral chamber (Table 1). The evolutionary history was inferred based on partial 16S rRNA gene sequences using neighbor-joining analysis. Bootstrap percentages above $50 \%$ (based on 500 replicates) are shown next to the branches. The sequence of Aquifex pyrophilus (M83548) was used as outgroup to root the tree (not shown). Bar, two substitutions per 100 nucleotides. MAR, Mid-Atlantic Ridge. 

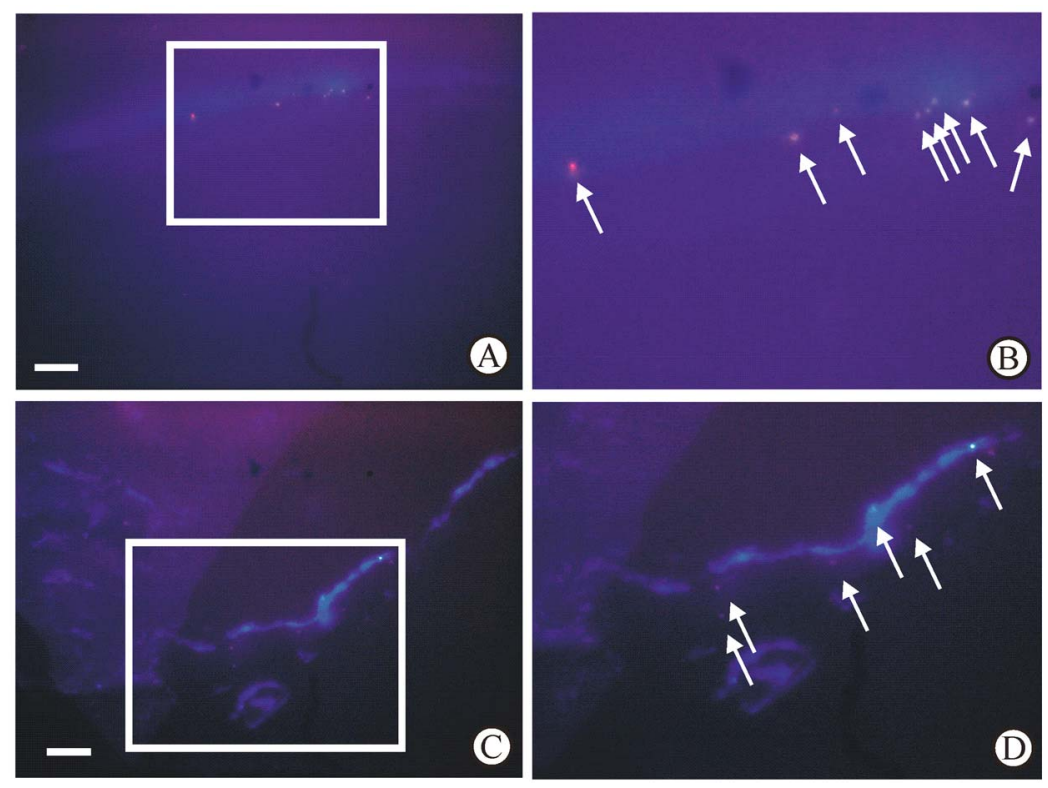

Figure 5. DAPI-stained thin sections (viewed with oil immersion at $1000 \times$ phase contrast microscopy) of olivine and basalt glass incubated in Hole 1301A. Cells are visible in microfractures (arrows). (a, c) Insets are (b, d) magnified. Bars are $10 \mu \mathrm{m}$.
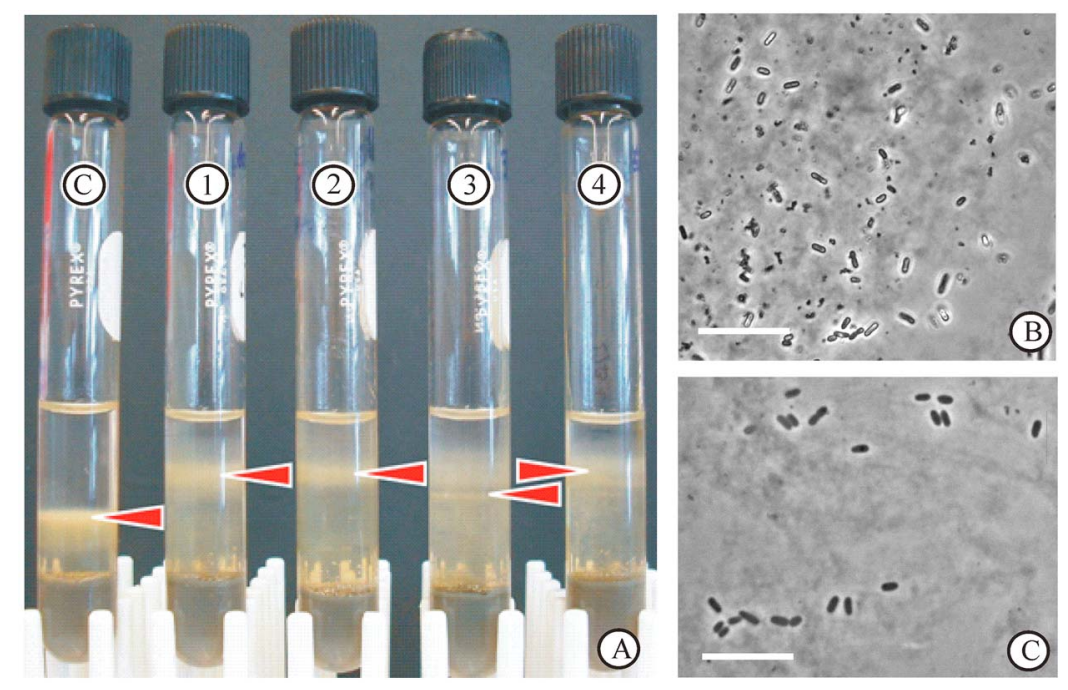

Figure 6. (a) $\mathrm{O}_{2} / \mathrm{FeCO}_{3}$ gradient tubes incubated for 4 days at $25^{\circ} \mathrm{C}$. Tube $\mathrm{C}$ is an uninoculated control; tubes $1-4$ were inoculated with representative strains isolated from 1301A. Microbial growth is indicated by discrete bands containing abundant microbes (as evidenced by microscopy) and variable band position in the oxycline in relation to the control. Flags indicate the position of microbial growth bands in 1-4 and abiotic iron oxides in C. (b, c) Two 1000× phase contrast images of microbes sampled from growth bands in Figure 6a. Bar equals $10 \mu \mathrm{M}$. 
Table 5. Results of Physiological Tests for 11 Strains Isolated From Minerals and Glasses Incubated in Hole $1301 \mathrm{~A}^{\mathrm{a}}$

\begin{tabular}{|c|c|c|c|c|c|}
\hline Strain Name & Phylotype & Fe(II) Oxidation & $\mathrm{NO}_{3}^{-}$Reduction & $\mathrm{NO}_{2}^{-}$Reduction & $\begin{array}{l}\mathrm{N}_{2} \text { Production } \\
\text { (Denitrification) }\end{array}$ \\
\hline $1 \mathrm{c} .9$ & Alcanivorax & + & + & + & + \\
\hline $5 c .5$ & Aurantimonas & + & + & + & + \\
\hline $1 \mathrm{c} .1$ & Halomonas & + & + & - & - \\
\hline $1 \mathrm{~d} .3$ & Marinobacter & + & + & + & + \\
\hline $1 \mathrm{c} .10$ & Marinobacter & + & - & - & - \\
\hline $3 \mathrm{~d} .6$ & Marinobacter & + & + & + & + \\
\hline 1c. 14 & Microbacterium & + & + & + & + \\
\hline $3 \mathrm{~d} .4$ & Nitratireductor & + & + & - & - \\
\hline $1 \mathrm{~b} .2$ & Pseudomonas & + & + & + & - \\
\hline 5a.1 & Rhodotorula & - & - & - & - \\
\hline 1a. 6 & Stappia & + & + & + & + \\
\hline
\end{tabular}

a + or - indicates "yes" or "no" for the ability to perform each physiological characteristic.

tubes containing fayalite $\left(\mathrm{Fo}_{0}\right)$ was twice as fast as in the olivine $\left(\mathrm{Fo}_{90}\right)$ tubes. Results from $\mathrm{Fe}$ (III) reduction tests for strain 3d.6 showed no change in the amounts of lactate, acetate, succinate, or pyruvate over a 5 week period.

[31] Four strains related to known iron oxidizers and nitrate reducers (Nitratireductor, Halomonas, Marinobacter sp. 1c.10, and Pseudomonas) were tested for the ability to grow on olivine utilizing nitrate as a terminal electron acceptor in the defined medium. All four strains grew anaerobically on olivine using nitrate over the course of the 3 week experiment (Figure $7 \mathrm{~b}$ ).

\section{Discussion}

[32] This is the first long-term deployment of microbial enrichment flow cells using osmotically driven pumps in a subseafloor borehole. The three flow cell pairs worked as designed. This was confirmed by the numbers of microorganisms present in the minerals in the "experimental" chambers compared to "control" chambers. Flow through the chambers was also indicated by the pattern of dark and light foam plugs, presumably from iron sulfides (Figure 2b). Circulation through the system was greater in the fourth year when the osmotic pump rate increased. The contamination of the "control" flow cells could have been caused by compromised filters or seawater entering the flow cells through the broken pumps as the instrument string was hoisted to the ship. The lower number of cells in control minerals relative to experimental minerals indicates that the filters did work to some extent (Table 2). If seawater entered as backflow through the broken osmotic pumps, then chamber $\mathrm{D}^{\prime}$ (which was closest to the pumps) should have
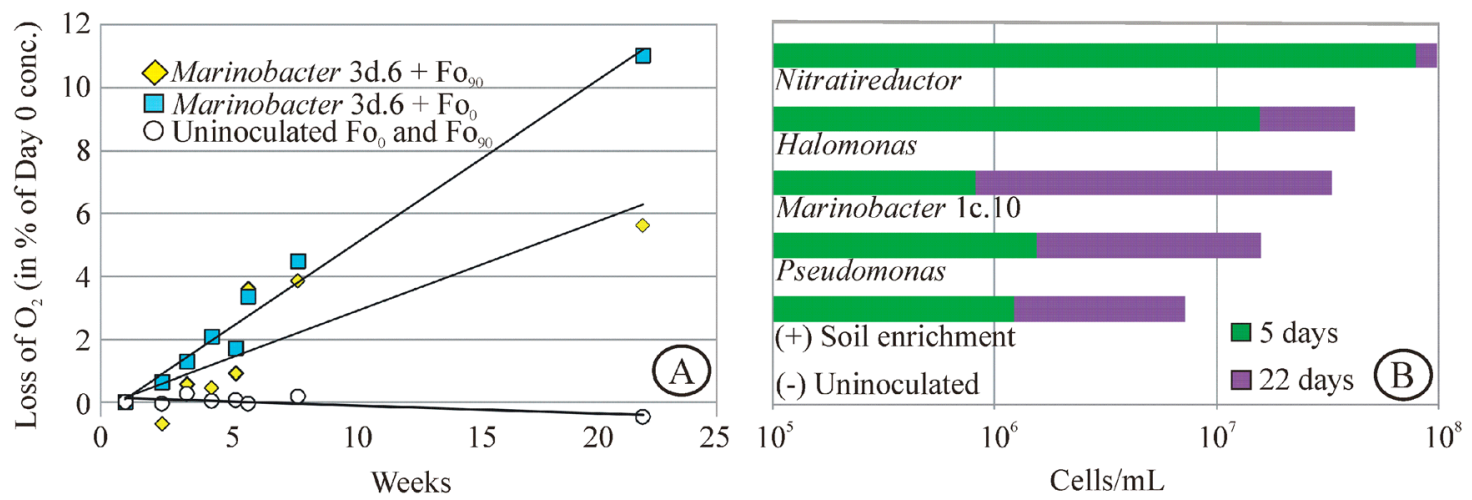

Figure 7. (a) Growth of Marinobacter sp. $3 \mathrm{~d} .6$ as evidenced by $\mathrm{O}_{2}$ loss over time when compared to uninoculated controls. Cells were grown with olivine containing $10 \% \mathrm{Fe}(\mathrm{II})\left(\mathrm{Fo}_{90}\right)$ or $100 \% \mathrm{Fe}(\mathrm{II})\left(\mathrm{Fo}_{0}\right)$ in marine mineral medium and $21 \%$ oxygen in the headspace. $\mathrm{O}_{2}$ respiration is reported as loss of $\mathrm{O}_{2}$ over a period of 22 weeks. (b) Growth of four 1301A isolates in olivine media supplemented with $10 \mathrm{mM}$ nitrate. Included are an uninoculated negative control (minus sign) and an organotroph aquarium soil enrichment as a positive control (plus sign). No bar in the negative control indicates no growth. Growth (putatively indicating anaerobic nitrate-dependent iron oxidation using olivine) is reported as cells/mL over initial inoculum by cell counts on days 5 and 22 . 
been more heavily contaminated than the other control chambers. We did not find this to be the case.

[33] Our initial goal was to isolate thermophilic iron oxidizers or iron reducers from the minerals incubated in Hole 1301A, based on our understanding that conditions at depth around Hole 1301A were similar to those around Hole $1026 \mathrm{~B}\left(\sim 64^{\circ} \mathrm{C}\right.$, altered and reduced fluids) once downflow of bottom water into Hole 1301A stopped. Our enrichments using olivine as a source of $\mathrm{Fe}$ (II) in low-oxygen autotrophic media did not produce any growth, and the same was true for our Fe(III) reduction media. We also opted to isolate organotrophic organisms that could then be screened for the ability to oxidize iron as an alternate to autotrophic iron oxidizers [Emerson et al., 2010]. We were successful in this effort, yet much work remains to be done to link these particular organisms to iron oxidation and nitrate reduction in the ocean crust and to provide proof for chemolithoautotrophic growth.

[34] The mesophiles we isolated are either thermotolerant remnants of the seawater microbial community that accumulated in the first 3 years (surviving $64^{\circ} \mathrm{C}$ for $\sim 1$ year), or they originated from warm formation water and colonized the mineral surfaces during the final year of instrument deployment. The thermophiles may have originated from either formation water or seawater. The 84 colonies we sequenced clustered within only nine phylotypes, all closely related to known inhabitants of deep seawater, sediment, basalt, or hydrothermal deposits. Earlier researchers have identified microbes from seafloor basalts [Mason et al., 2009; Santelli et al., 2008; Einen et al., 2008; Lysnes et al., 2003], but in environments different from the one we studied. Most of the earlier work was done on seafloor basalts from cold, aerobic conditions, whereas Hole 1301A's environment changed drastically from cold and aerobic to warm and anaerobic during the last year of incubation. Lysnes et al. [2003] described a community of subsurface microorganisms in the Australian-Antarctic Discordance very similar to those found in Hole 1301A and cultured aerobic heterotrophs similar to those we have cultured from Hole 1301A. The phylotypes that were common between the Lysnes et al. study and ours are Pseudomonas, Marinobacter, Halomonas, and Actinobacteria. Similar organisms were also isolated by Rathsack et al. [2009] from Mid-Atlantic Ridge (MAR) basalt, basalt glass, sediment, and seawater. These organisms include Marinobacter, Halomonas, Pseudomonas, Microbacterium, and Nitratireductor, all of which we have isolated from Hole 1301A. Orcutt et al. [2010b] found evidence suggesting that iron oxidizers were present in Hole 1301A during the low temperature period and that these microbial types were eliminated once the temperature increased. In support of this, we could not isolate any thermophilic iron oxidizers and iron reducers. However, Orcutt et al. [2010b] analyzed DNA sequences obtained from rock and mineral chips incubated in a simultaneous experiment in Hole 1301A and found that the majority of amplified sequences belonged to Firmicutes. Our isolates appear to be more indicative of inhabitants residing in cooler, more oxygenated regions of the surface and upper subsurface of the ocean crust than dominant members of the reducing hydrothermal environment in the deep subsurface.

[35] All phylotypes we found are common in seafloor, subseafloor, or hydrothermal ecosystems. The Halomonas strain belongs to Halomonas Group 2A, which was previously identified as a subseafloor clade in JFR [Kaye et al., 2010]. The yeast belongs to a genus (Rhodotorula) with species ubiquitous in deep marine habitats [Nagano et al., 2010; Connell et al., 2009; Nagahama et al., 2006] and have been suggested to play a role in metal cycling in seafloor volcanic environments [Connell et al., 2009]. They were also found to be among the earliest colonizers of basalts in low-temperature seafloor systems [Connell et al., 2009]. It is unlikely that our yeast isolate is a contaminant from seawater that may have entered the chambers of the flow cell during the string retrieval since all our other isolates are common to deep ocean crustal habitats. Moreover, Rhodotorula was abundantly common to most flow cell minerals, indicating its ubiquitous presence in the well water prior to the string retrieval. We propose that our isolate colonized the incubated Hole 1301A minerals during the first 3 years of the experiment when cooler borehole water was entering the flow cells. In summary, we think it is more likely that our isolates are representatives of the borehole fluids rather than contamination from the ocean column as the string was recovered.

[36] The range of total cell densities we found (20 to $400 \times 10^{6}$ cells $\mathrm{g} \mathrm{mineral}^{-1}$ ) are within values reported earlier for seafloor basalts [Einen et al., 2008; Santelli et al., 2008, 2009], the difference being that earlier reports analyzed densities in whole basalt rock, while our experiment was a flowthrough enrichment on minerals and glasses. We found that the easily weathered Fe(II)-bearing olivines contained the highest total cell densities, while the iron-poor minerals (diopside, anorthite, bytownite and K-feldspar) showed the lowest cell densities (Table 2). This is indicative of a microbial 
community potentially supported by neutrophilic iron oxidation. Olivine weathers at a faster rate than other silicate minerals [Eggleton et al., 1987], and this tendency increases with temperature [Hausrath et al., 2008]. Olivine and glass weather at relatively similar rates, however olivine only contains Fe(II) while basalt and basalt glass have a significant proportion of their iron as Fe(III) [Holloway, 2004]. We hypothesize that under similar conditions and iron content, the proportion of $\mathrm{Fe}(\mathrm{II})$ released during olivine weathering is greater than that of glass or other silicate minerals found in basalt. Apatite (a phosphate-rich mineral) had cell densities comparable to forsterite, hornblende, obsidian and augite. This apatite enrichment is consistent with previous work, which indicated that microbes preferentially colonize apatite in phosphate-free media [Rogers and Bennett, 2004; Bailey et al., 2009].

[37] Culturable mesophilic organotrophs were a small part $(\sim 1-13 \%)$ of the total microbial community. The largest densities of culturable organotrophs were found on the two iron-bearing olivines, while most other minerals had smaller, similar cell abundances. Organotrophic thermophiles were only grown from minerals contained in flow cell 1, and were almost exclusively present in the $\mathrm{Fo}_{90}$ olivine and fayalite. The community of microbes from fayalite was almost $100 \%$ represented by thermophiles. Finding more cells by culturing than by direct counting is likely explained by the presence of mature spores that escaped counting. Since spores stain poorly with the DAPI stain [Setlow et al., 2002], only the total number of vegetative cells were counted, and the total number of viable cells (including spores) was underestimated. Although we do not have DNA sequences for the thermophiles we have isolated, the cells stained as Gram positive organisms, which is indicative of Firmicutes (and spore-forming bacteria). Orcutt et al. [2010b] found putative thermophilic Firmicutes attached to the minerals they incubated in 1301A simultaneously with this study, and proposed that the thermophiles increased in abundance in the last year when the temperature increased. The thermophiles we have isolated may be representative of spore-forming organotrophs from this group of bacteria.

[38] The structure of the microbial community very likely evolved during the 4 years of the experiment, but our experimental was not designed to monitor this evolution. The isolates selected from the marine R2A plates were similarly distributed across all minerals, yet this is not a comprehensive comparison of microbial community structure across different minerals since these isolates only represent a selected subset of culturable mesophiles. Our sampling focused on targeting a diversity of colony morphologies rather than random selection or the statistical relevance of each colony type.

[39] All of our isolates are related to known nitrate dissimilators, while Marinobacter spp. and P. stutzeri (close relatives to two of our isolates) were shown to anaerobically oxidize iron with nitrate $[$ Straub et al., 1996; Edwards et al., 2003a]. Our results are consistent with earlier observations that nitratereducing microbes may be common in the subseafloor of JFR [Cowen et al., 2003; Wheat et al., 2010]. A large majority of our mesophilic phylotypes were found to be nitrate reducers and iron oxidizers. These physiotypes may be common in seawater recharge zones where an influx of oxidants from seawater into subsurface basalt with $\mathrm{Fe}(\mathrm{II})$-bearing minerals creates a chemical disequilibrium that can fuel microbial growth. However, we cannot deduce from these results that nitrate reducers and iron oxidizers are a dominant part of the subsurface community because the strains we analyzed were selected based on colony diversity and not randomly chosen.

\section{Conclusions}

[40] Our goals were to test a novel, long-term, flow-through system for in situ mineral incubation in the ocean crust and to study the microbial colonization preference for minerals and glasses. We succeeded in isolating and culturing microbes from the upper ocean crust, which were enriched in situ using igneous minerals and glasses as substrates. Samples were analyzed for total cell density and abundance of culturable organotrophs, and isolates were phylogenetically characterized. The highest total cell density and number of culturable organotrophs were found on $\mathrm{Fe}(\mathrm{II})$-bearing olivines $\left(\mathrm{Fo}_{0}\right.$ and $\left.\mathrm{Fo}_{90}\right)$. Of the twelve minerals and glasses analyzed, over $40 \%$ of the total cells were extracted from only two minerals $\left(\mathrm{Fo}_{0}\right.$ and $\left.\mathrm{Fo}_{90}\right)$. Among olivines, $\mathrm{Fo}_{0}$ and $\mathrm{Fo}_{90}$ had significantly higher cell densities than the iron-poor olivine forsterite $\left(\mathrm{Fo}_{100}\right)$. Thermophilic organotrophs were only cultured from $\mathrm{Fo}_{0}$ and $\mathrm{Fo}_{90}$. We found that most culturable oligotrophs we have isolated from the igneous phases incubated in Hole 1301A are capable of growth by nitrate reduction and also have the ability to oxidize iron. Nitrate reduction in situ is supported by the observation that nitrate in the borehole was above $10 \mu \mathrm{M}$ for the first 2 years and then declined [Wheat et al., 2010]. Our results suggest that oligotrophic microbes with the ability to oxidize iron are an integral part of the micro- 
bial community residing in the upper basaltic crust of JFR. These physiotypes may also be common inhabitants of seawater recharge zones in subseafloor basalts containing olivine.

[41] The in situ incubation of partitioned igneous minerals and glasses common in subseafloor basalt gives a unique insight into microbe-mineral interactions in the ocean crust. The development and implementation of novel techniques and devices (such as microbial flow cells) to evaluate subseafloor habitats and the ocean crust biome is vital to obtaining a comprehensive view of ocean crust microbiology. This study is the first quantitative analysis of microbial density associated with different minerals and mineraloids from ocean crust basalts. It is apparent that the association of microbes with minerals is controlled by mineral composition. This gives support to the hypothesis that endolithic microbial communities will have higher densities near minerals exhibiting greater thermodynamic disequilibrium with the surrounding fluid or seawater. It also proves that the heterogeneous distribution of minerals in marine igneous rocks will directly influence the distribution of surfaceattached microbial communities in ocean crust.

\section{Acknowledgments}

[42] The subseafloor flow cell enrichment chambers were funded by a small grant from the Ocean Drilling Program. The idea for the flow cells was developed at a workshop in Bergen, Norway (2002), which was supported by the University of Bergen and the Ocean Drilling Program. We would like to acknowledge the crews of the submersible Alvin and the RV Atlantis and JOIDES Resolution. William Rugh contributed to the design and manufactured the flow cells. This work was also funded by NASA grant NNX08AO22G, NSF OCE 0727119 to C.G.W., NSF OCE 0452333 to S.M.S., and OCE-0550713 and OCE-0727952 to A.T.F., PSU, and OSU. Unimin Co. provided the $\mathrm{Fo}_{90}$ olivine.

\section{References}

Amend, J. P., and A. Teske (2005), Expanding frontiers in deep subsurface microbiology, Palaeogeogr. Palaeoclimatol. Palaeoecol., 219, 131-155, doi:10.1016/j.palaeo.2004.10.018.

Bailey, B., A. Templeton, H. Staudigel, and B. Tebo (2009), Utilization of substrate components during basaltic glass colonization by Pseudomonas and Shewanella isolates, Geomicrobiol. J., 26, 648-656, doi:10.1080/01490450903263376.

Baker, G. C., J. J. Smith, and D. A. Cowan (2003), Review and re-analysis of domain-specific $16 \mathrm{~S}$ primers, J. Microbiol. Methods, 55(3), 541-555, doi:10.1016/j.mimet.2003.08.009.

Beal, E. J., C. H. House, and V. J. Orphan (2009), Manganeseand iron-dependent marine methane oxidation, Science, 325, 184-187, doi:10.1126/science.1169984.
Becker, K., and A. T. Fisher (2008), Borehole packer tests at multiple depths resolve distinct hydrologic intervals in 3.5 Ma upper oceanic crust, eastern flank of Juan de Fuca Ridge, J. Geophys. Res., 113, B07105, doi:10.1029/ 2007JB005446.

Bennett, P. C., A. S. Engel, and J. A. Roberts (2006), Counting and imaging bacteria on mineral surfaces, in Methods of Investigating Microbial-Mineral Interactions, CMS Workshop Lectures, vol. 14, edited by J. Patricia, A. Maurice, and Lesley A. Warren, pp. 37-78, Clay Miner. Soc., Chantilly, Va.

Cole, J. R., et al. (2009), The Ribosomal Database Project: Improved alignments and new tools for rRNA analysis, Nucleic Acids Res., 37, D141-D145, doi:10.1093/nar/ gkn879.

Connell, L., A. Barrett, A. Templeton, and H. Staudigel (2009), Fungal diversity associated with an active deep sea volcano: Vailulu'u Seamount, Samoa, Geomicrobiol. J., 26, 597-605, doi:10.1080/01490450903316174.

Cook, A. E., and P. R. Meyers (2003), Rapid identification of filamentous actinomycetes to the genus level using genusspecific 16S rRNA gene restriction fragment patterns, Int. J. Syst. Evol. Microbiol., 53, 1907-1915, doi:10.1099/ ijs.0.02680-0.

Cowen, J. P., S. J. Giovannoni, F. Kenig, H. P. Johnson, D. A. Butterfield, M. S. Rappe, M. Hutnak, and P. Lam (2003), Fluids from aging ocean crust that support microbial life, Science, 299, 120-123, doi:10.1126/science.1075653.

Daughney, C. J., J. P. Rioux, D. Fortin, and T. Pichler (2004), Laboratory investigation of the role of bacteria in the weathering of basalt near deep sea hydrothermal vents, Geomicrobiol. J., 21, 21-31, doi:10.1080/01490450490253437.

Edwards, K. J., D. R. Rogers, C. O. Wirsen, and T. M. McCollom (2003a), Isolation and characterization of novel psychrophilic, neutrophilic, Fe-oxidizing chemolithoautotrphic alpha- and gamma-proteobacteria from the deep-sea, Appl. Environ. Microbiol., 69, 2906-2913, doi:10.1128/AEM.69.5.29062913.2003.

Edwards, K. J., W. Bach, and D. R. Rogers (2003b), Geomicrobiology of the ocean crust: A role for chemoautotrophic Fe-bacteria, Biol. Bull., 204, 180-185, doi:10.2307/1543555.

Eggleton, R. A., C. Foudoulis, and D. Varkevisser (1987), Weathering of basalt-Changes in rock chemistry and mineralogy, Clays Clay Miner., 35, 161-169, doi:10.1346/ CCMN.1987.0350301.

Einen, J., I. H. Thorseth, and L. Ovreas (2008), Enumeration of Archaea and bacteria in seafloor basalt using real-time quantitative PCR and fluorescence microscopy, FEMS Microbiol. Lett., 282(2), 182-187, doi:10.1111/j.1574-6968. 2008.01119.x.

Elderfield, H., C. G. Wheat, M. J. Mottl, C. Monnin, and B. Spiro (1999), Fluid and geochemical transport through oceanic crust: A transect across the eastern flank of the Juan de Fuca Ridge, Earth Planet. Sci. Lett., 172, 151-165, doi:10.1016/S0012-821X(99)00191-0.

Emerson, D., J. A. Rentz, T. G. Lilburn, R. E. Davis, H. Aldrich, C. Chan, and C. Moyer (2007), A novel lineage of proteobacteria involved in formation of marine Fe-oxidizing microbial mat communities, PLoS ONE, 2(8), e667, doi:10.1371/journal. pone.0000667.

Emerson, D., E. J. Fleming, and J. M. McBeth (2010), Ironoxidizing bacteria: An environmental and genomic perspective, Annu. Rev. Microbiol., 64, 561-583.

Fisher, A. T., et al. (2003), Hydrothermal recharge and discharge across $50 \mathrm{~km}$ guided by seamounts on a young ridge flank, Nature, 421, 618-621, doi:10.1038/nature01352. 
Fisher, A. T., and the Expedition 301 Scientists (2005a), Scientific and technical design and deployment of long-term, subseafloor observatories for hydrogeologic and related experiments, in Juan de Fuca Hydrogeology, Proc. Integr. Ocean Drill. Program, 301, doi:10.2204/iodp.proc.301.103.2005.

Fisher, A. T., T. Urabe, A. Klaus, and the IODP Expedition 301 Project Team (2005b), IODP Expedition 301 installs three borehole crustal observatories, prepares for threedimensional, cross-hole experiments in the northeastern Pacific Ocean, Sci. Drill., 1, 6-11.

Fisk, M. R., I. H. Thorseth, E. Urbach, and S. J. Giovannoni (2000), Investigation of microorganisms and DNA from subsurface thermal water and rock from the east flank of Juan de Fuca Ridge, Proc. Ocean Drill. Program Sci. Results, 168, 167-174.

Hatzenpichler, R., E. V. Lebedeva, E. Spieck, K. Stoecker, A. Richter, H. Daims, and M. Wagner (2008), A moderately thermophilic ammonia-oxidizing crenarchaeote from a hot spring, Proc. Natl. Acad. Sci. U. S. A., 105, 2134-2139, doi:10.1073/pnas.0708857105.

Hausrath, E. M., A. H. Treiman, E. Vicenzi, D. L. Bish, D. Blake, P. Sarrazin, T. Hoehler, I. Midtkandal, A. Steele, and S. L. Brantley (2008), Short- and long-term olivine weathering in Svalbard: Implications for Mars, Astrobiology, 8, 1079-1092, doi:10.1089/ast.2007.0195.

Heberling, C., R. P. Lowell, L. Liu, and M. R. Fisk (2010), Extent of the microbial biosphere in the oceanic crust, Geochem. Geophys. Geosyst., 11, Q08003, doi:10.1029/ 2009GC002968

Holloway, J. R. (2004), Redox reactions in seafloor basalts: Possible insights into silicic hydrothermal systems, Chem. Geol., 210, 225-230, doi:10.1016/j.chemgeo.2004.06.009.

Huber, J. A., H. P. Johnson, D. A. Butterfield, and J. A. Baross (2006), Microbial life in ridge flank crustal fluids, Environ. Microbiol., 8, 88-99, doi:10.1111/j.1462-2920.2005.00872.x.

Hutnak, M., A. T. Fisher, L. Zuhlsdorff, V. Spiess, P. H. Stauffer, and C. W. Gable (2006), Hydrothermal recharge and discharge guided by basement outcrops on 0.7-3.6 Ma seafloor east of the Juan de Fuca Ridge: Observations and numerical models, Geochem. Geophys. Geosyst., 7, Q07002, doi:10.1029/2006GC001242.

Jannasch, H. W., C. G. Wheat, J. N. Plant, M. Kastner, and D. S. Stakes (2004), Continuous chemical monitoring with osmotically pumped water samplers: OsmoSampler design and applications, Limnol. Oceanogr. Methods, 2, 102-113, doi:10.4319/lom.2004.2.102.

Kashefi, K., and D. R. Lovley (2003), Extending the upper temperature limit for life, Science, 301, 934, doi:10.1126/ science. 1086823.

Kashefi, K., J. M. Tor, D. E. Holmes, C. V. Gaw Van Praah, A.-L. Reysenbach, and D. R. Lovley (2002), Geoglobus ahangari gen. nov., sp. nov., a novel hyperthermophilic archaeon capable of oxidizing organic acids and growing autotrophically on hydrogen with Fe(III) serving as the sole electron acceptor, Int. J. Syst. Evol. Microbiol., 52, 719-728, doi:10.1099/ijs.0.01953-0.

Kaye, J. Z., J. B. Sylvan, K. J. Edwards, and J. A. Baross (2010), Halomonas and Marinobacter ecotypes from hydrothermal vent, subseafloor and deep-sea environments, FEMS Microbiol. Ecol., 75, 123-133.

Kniemeyer, O., et al. (2007), Anaerobic oxidation of shortchain hydrocarbons by marine sulphate-reducing bacteria, Nature, 449, 898-901, doi:10.1038/nature06200.

Lang, S. Q., D. A. Butterfield, M. D. Lilley, H. P. Johnson, and J. I. Hedges (2006), Dissolved organic carbon in ridge-axis and ridge-flank hydrothermal systems, Geochim. Cosmochim. Acta, 70, 3830-3842, doi:10.1016/j.gca.2006.04.031.

Leboffe, M. J., and B. E. Pierce (2005), A Photographic Atlas for the Microbiology Laboratory, 3rd ed., pp. 68-70, Morton, Englewood, Colo.

Lehman, R. M. (2007), Understanding of aquifer microbiology is tightly linked to sampling approaches, Geomicrobiol. J., 24, 331-341.

Ludwig, W., et al. (2004), ARB: A software environment for sequence data, Nucleic Acids Res., 32, 1363-1371, doi:10.1093/nar/gkh293.

Lysnes, K., T. Torsvik, I. H. Thorseth, and R. B. Pedersen (2003), Microbial populations in ocean floor basalt: Results from ODP Leg 187, Proc. Ocean Drill. Program Sci. Results, $187,1-27$.

Mason, O., C. Di Meo-Savoie, J. Van Nostrand, J. Zhou, M. Fisk, and S. Giovannoni (2009), Prokaryotic diversity, distribution, and insights into their role in biogeochemical cycling in marine basalts, ISME J., 3, 231-242, doi:10.1038/ ismej.2008.92.

Mason, O., T. Nakagawa, M. Rosner, J. Van Nostrand, J. Zhou, A. Maruyama, M. Fisk, and S. Giovannoni (2010), First investigation of the microbiology of the deepest layer of ocean crust, PLOS ONE, 5(11), e15399, doi:10.1371/journal. pone.0015399.

Mazza, P., P. Monciardini, L. Cavaletti, M. Sosio, and S. Donadio (2003), Diversity of Actinoplanes and related genera isolated from an Italian soil, Microbial Ecol., 45, 362-372, doi:10.1007/s00248-002-2038-4.

McCarthy, M. D., S. R. Beaupre, B. D. Walker, I. Voparil, T. P. Guilderson, and E. R. M. Druffel (2011), Chemosynthetic origin of ${ }^{14} \mathrm{C}$-depleted dissolved organic matter in a ridge-flank hydrothermal system, Nat. Geosci., 4, 32-36, doi:10.1038/NGEO1015.

Nagahama, T., M. Hamamoto, and K. Horikoshi (2006), Rhodotorula pacifica sp nov., a novel yeast species from sediment collected on the deep-sea floor of the north-west Pacific Ocean, Int. J. Syst. Evol. Microbiol., 56, 295-299, doi:10.1099/ijs.0.63584-0.

Nagano, Y., T. Nagahama, Y. Hatada, T. Nunoura, H. Takami, J. Miyazaki, K. Takai, and K. Horikoshi (2010), Fungal diversity in deep-sea sediments-The presence of novel fungal groups, Fungal Ecol., 3, 316-325, doi:10.1016/j.funeco. 2010.01.002.

Nakagawa, S., F. Inagaki, Y. Suzuki, B. Steinsbu, M. Lever, K. Takai, B. Engelen, Y. Sako, C. G. Wheat, and K. Horikoshi (2006), Microbial community in black rust exposed to hot ridge flank crustal fluids, Appl. Environ. Microbiol., 72, 6789-6799, doi:10.1128/AEM.01238-06.

Orcutt, B., C. G. Wheat, and K. Edwards (2010a), Subseafloor ocean crust microbial observatories: Development of FLOCS (flow-through osmo colonization system) and evaluation of borehole construction materials, Geomicrobiol. J., 27, 143-157, doi:10.1080/01490450903456772.

Orcutt, B., W. Bach, K. Becker, A. Fisher, M. Hentscher, B. Toner, C. G. Wheat, and K. Edwards (2010b), Colonization of subsurface microbial observatories deployed in young ocean crust, ISME J., 5, 692-703, doi:10.1038/ismej.2010.157.

Pruesse, E., C. Quast, K. Knittel, B. M. Fuchs, W. Ludwig, J. Peplies, and F. O. Glockner (2007), SILVA: A comprehensive online resource for quality checked and aligned ribosomal RNA sequence data compatible with ARB, Nucleic Acids Res., 35, 7188-7196, doi:10.1093/nar/gkm864.

Rathsack, K., E. Stackebrandt, J. Reitner, and G. Schumann (2009), Microorganisms isolated from deep sea low- 
temperature influenced oceanic crust basalts and sediment samples collected along the Mid-Atlantic Ridge, Geomicrobiol. J., 26, 264-274, doi:10.1080/01490450902892456.

Rogers, J. R., and P. C. Bennett (2004), Mineral stimulation of subsurface microorganisms: Release of limiting nutrients from silicates, Chem. Geol., 203, 91-108, doi:10.1016/j.chemgeo. 2003.09.001.

Saitou, N., and M. Nei (1987), The neighbor-joining method: A new method for reconstructing phylogenetic trees, Mol. Biol. Evol., 4(4), 406-425.

Santelli, C. M., B. M. Orcutt, E. Banning, W. Bach, C. L. Moyer, M. L. Sogin, H. Staudigel, and K. J. Edwards (2008), Abundance and diversity of microbial life in ocean crust, Nature, 453, 653-656, doi:10.1038/nature06899.

Santelli, C. M., V. P. Edgcomb, W. Bach, and K. J. Edwards (2009), The diversity and abundance of bacteria inhabiting seafloor lavas positively correlate with rock alteration, Environ. Microbiol., 11, 86-98, doi:10.1111/j.1462-2920.2008.01743.x.

Schrenk, M. O., D. S. Kelley, J. R. Delaney, and J. A. Baross (2003), Incidence and diversity of microorganisms within the walls of an active deep-sea sulfide chimney, Appl. Environ. Microbiol., 69, 3580-3592, doi:10.1128/AEM.69.6.35803592.2003

Setlow, B., C. A. Loshon, P. C. Genest, A. E. Cowan, C. Setlow, and P. Setlow (2002), Mechanisms of killing spores of Bacillus subtilis by acid, alkali and ethanol, J. Appl. Microbiol., 92, 362-375, doi:10.1046/j.1365-2672.2002.01540.x.

Smith, A., R. Popa, M. Fisk, M. Nielsen, G. Wheat, H. Jannasch, A. Fisher, and S. Sievert (2008), Subseafloor microbial colonization of igneous minerals and glasses, Eos Trans. $A G U$, 89(53), Fall Meet. Suppl., Abstract B53C-0506.

Stevens, T. (1997), Lithoautotrophy in the subsurface, FEMS Microbiol. Rev., 20, 327-337, doi:10.1111/j.1574-6976.1997. tb00318.x.

Straub, K. L., M. Benz, B. Schink, and F. Widdel (1996), Anaerobic, nitrate-dependent microbial oxidation of ferrous iron, Appl. Environ. Microbiol., 62, 1458-1460.

Tamura, K., J. Dudley, M. Nei, and S. Kumar (2007), MEGA4: Molecular Evolutionary Genetics Analysis (MEGA) software version 4.0, Mol. Biol. Evol., 24(8), 1596-1599, doi:10.1093/ molbev/msm092.

Templeton, A. S., B. Tebo, H. Staudigel, B. Bailey, L. Haucke, and T. Trainor (2005a), Fe(II) and Mn(II) oxidation and biomineralization within basalt-hosted lithoautotrophic biofilms, Geochim. Cosmochim. Acta, 69, A672.
Templeton, A. S., H. Staudigel, and B. M. Tebo (2005b), Diverse Mn(II)-oxidizing bacteria isolated from submarine basalts at Loihi Seamount, Geomicrobiol. J., 22, 127-139, doi:10.1080/01490450590945951.

Thorseth, I. H., T. Torsvik, V. Torsvik, F. L. Daae, and R. B. Pedersen (2001), Diversity of life in ocean floor basalt, Earth Planet. Sci. Lett., 194, 31-37, doi:10.1016/S0012-821X(01) 00537-4.

Underwood, M., K. D. Hoke, A. T. Fisher, E. R. Giambalvo, E. E. Davis, and L. Zühlsdorff (2005), Provenance, stratigraphic architecture, and hydrogeologic effects of turbidites in northwestern Cascadia Basin, Pacific Ocean, J. Sediment. Res., 75(1), 149-164, doi:10.2110/jsr.2005.012.

Ver Eecke, H. C., D. S. Kelley, and J. F. Holden (2009), Abundances of hyperthermophilic autotrophic Fe(III) oxide reducers and heterotrophs in hydrothermal sulfide chimneys of the northeastern Pacific Ocean, Appl. Environ. Microbiol., 75, 242-245, doi:10.1128/AEM.01462-08.

Walker, B. D., M. D. McCarthy, A. T. Fisher, and T. P. Guiderson (2008), Dissolved inorganic carbon isotopic composition of low-temperature axial and ridge-flank hydrothermal fluids of the Juan de Fuca Ridge, Mar. Chem., 108, 123-136, doi:10.1016/j.marchem.2007.11.002.

Wheat, C. G., and M. J. Mottl (2000), Composition of pore and spring waters from Baby Bare: Global implications of geochemical fluxes from a ridge flank hydrothermal system, Geochim. Cosmochim. Acta, 64, 629-642, doi:10.1016/ S0016-7037(99)00347-6.

Wheat, C. G., M. J. Mottl, and M. Rudniki (2002), Trace element and REE composition of a low-temperature ridge flank hydrothermal spring, Geochim. Cosmochim. Acta, 66, 3693-3705, doi:10.1016/S0016-7037(02)00894-3.

Wheat, C. G., H. W. Jannasch, A. T. Fisher, K. Becker, J. Sharkey, and S. Hulme (2010), Subseafloor seawaterbasalt-microbe reactions: Continuous sampling of borehole fluids in a ridge flank environment, Geochem. Geophys. Geosyst., 11, Q07011, doi:10.1029/2010GC003057.

Whitman, W. B., D. C. Coleman, and W. J. Wiebe (1998), Prokaryotes: The unseen majority, Proc. Natl. Acad. Sci. U. S. A., 95, 6578-6583, doi:10.1073/pnas.95.12.6578.

Zhou, H. Y., J. T. Li, X. T. Peng, J. Meng, F. P. Wang, and Y. C. Ai (2009), Microbial diversity of a sulfide black smoker in main endeavour hydrothermal vent field, Juan de Fuca Ridge, J. Microbiol., 47, 235-247, doi:10.1007/ s12275-008-0311-z. 